\title{
Preparation and injection of fluid tracers during IODP Expedition 327, eastern flank of Juan de Fuca Ridge ${ }^{1}$
}

\author{
A.T. Fisher, ${ }^{2}$ J. Cowen, ${ }^{2}$ C.G. Wheat, ${ }^{2}$ and J.F. Clark ${ }^{3}$
}

\section{Chapter contents}

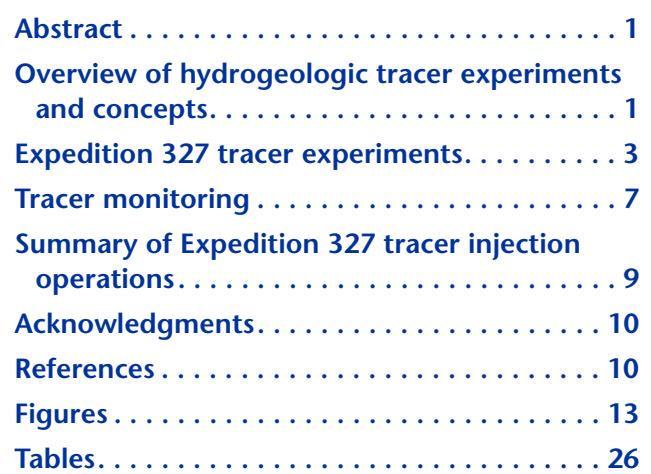

${ }^{1}$ Fisher, A.T., Cowen, J., Wheat, C.G., and Clark, J.F., 2011. Preparation and injection of fluid tracers during IODP Expedition 327, eastern flank of Juan de Fuca Ridge. In Fisher, A.T., Tsuji, T., Petronotis, K., and the Expedition 327 Scientists, Proc. IODP, 327: Tokyo (Integrated Ocean Drilling Program Management International, Inc.).

doi:10.2204/iodp.proc.327.108.2011

2Expedition 327 Scientists' addresses.

${ }^{3}$ Department of Earth Science and Program of Environmental Studies, University of California, Santa Barbara, Santa Barbara CA 93106, USA.

\section{Abstract}

Multiple tracers were pumped into upper basement around Hole U1362B during Integrated Ocean Drilling Program (IODP) Expedition 327 as part of a single- and cross-hole tracer experiment on the eastern flank of Juan de Fuca Ridge. Tracers injected were sulfur hexafluoride (dissolved gas), cesium chloride hexahydrate, erbium chloride, and holmium chloride hexahydrate (solutes), and several sizes of fluorescent microspheres and fluorescent-stained microbes filtered from surface seawater (particles). Tracers were injected as part of a $24 \mathrm{~h}$ pumping experiment intended to test a large volume of basement rock around Hole U1362B. We report on the design of the tracer experiment, methods used to prepare and inject tracers using shipboard mud and cement pump systems, and tools developed to permit shipboard and downhole sampling of injectate. Shore-based analysis of injectate samples will be essential for interpretation of long-term samples collected from subseafloor borehole observatories ("CORKs"). Borehole samples are being collected continuously within a long-term CORK installed in Hole U1362B after tracer injection was complete and within similar CORK systems installed in nearby boreholes before and during Expedition 327. CORK servicing expeditions are currently planned for summer 2011 and 2012. These expeditions and additional work in subsequent years will provide data and samples that will permit a quantitative assessment of tracer transport behavior in the upper ocean crust.

\section{Overview of hydrogeologic tracer experiments and concepts}

This paper describes the preparation and operations associated with tracer injection and sampling operations during Integrated Ocean Drilling Program (IODP) Expedition 327. Results from this experiment will not be known for several years, when data and samples will be collected and analyzed from several subseafloor borehole observatories ("CORKs"), but this paper provides background information on the motivation for this experiment and will be useful for researchers considering similar experiments on future drilling expeditions. Discussion of the configuration and installation of CORKs during Expedition 327 (and related IODP Expedition 301) is presented elsewhere (Fisher et al., 2005; Fisher, Wheat, et al.), as is a comprehensive summary of Expedition 327 
shipboard operations (see "Operations" in each site chapter of this volume). The regional geometry of the Expedition 327 tracer experiment is illustrated in Figure F1, which shows the distribution of boreholes (and associated observatory systems), basement outcrops, and the inferred dominant fluid flow direction in basement. We discuss experimental procedures after introducing tracer testing concepts and describing systems prepared for use during Expedition 327.

Numerous oceanographic studies have used geochemical tracers as indicators of the direction and rate of fluid flow beneath the seafloor. In most cases, geochemical tracers are naturally occurring (e.g., chlorinity, methane, silica, or ${ }^{14} \mathrm{C}$ ) (Elderfield et al., 1999; Lilley et al., 1993; Mottl and Wheat, 1994; Wheat and McDuff, 1995). Additional studies have benefited from use of surface seawater as a drilling fluid, creating a geochemical perturbation when deep-sea boreholes are drilled and cored (e.g., Mottl and Gieskes, 1990; Wheat et al., 2003, 2004). Fewer studies of subseafloor fluids have used artificial tracers introduced as part of a flow experiment. Solomon et al. (2009) deployed an automated tracer injection and fluid sampling system in a CORK deployed within a sedimentary interval seaward of the Middle America Trench, offshore of Costa Rica. Tracer injected into the borehole at a constant rate was sampled to assess both the flow of formation fluid in and out of the borehole and the relative direction of fluid transport. Wheat et al. (2010) deployed a similar injection and sampling system in a CORK completed in basement at a younger site on the eastern flank of Juan de Fuca Ridge. Both of these experiments were completed in single holes, and in each case the apparent rate of borehole exchange is considered to be a proxy for lateral transport rates in the formation surrounding the borehole.

Single-hole tracer experiments have been conducted in numerous aquifer systems on land, generally as a means to assess the bulk rate of fluid and solute transport around a borehole (e.g., Altman et al., 2002; Haggerty et al., 2001; Leap and Kaplan, 1988; Novakowski et al., 1998). There also is a rich literature involving land-based multihole tracer experiments in aquifers to assess formation and fluid flow properties, including dispersivity, effective porosity, particle transport rates, and the extent of soluteformation interactions (e.g., Becker et al., 2003; Birk et al., 2005; Göppert and Goldscheider, 2008; Hall et al., 1991). In some cases, multihole pumping and tracer experiments have been combined to acquire an understanding of linked physical-chemical transport processes (Dann et al., 2008; Day-Lewis et al.,
2006). Completing and interpreting the results of tracer experiments is inherently challenging, both because of technical difficulties in running the tests and controlling experimental conditions and because of complexities in formation property distributions and the scaling of hydrologic and solute transport processes (Brouyère et al., 2005; Khaleel, 1989; Neuman, 2005; Niemann and Rovey, 2009; Novakowski et al., 1995).

The conceptual basis for a hydrologic tracer injection experiment is illustrated schematically in Figure F2. Consider fluid flow through an aquifer system at a steady rate of $Q_{\text {in }}=Q_{\text {out }}$. Injectate containing a detectable tracer is added at a low rate (but with a high concentration) at an upgradient location, such that the initial tracer concentration in the aquifer is $C_{\text {in }}$. Fluid in the aquifer flows toward a downstream monitoring location while tracer mixing, spreading, and reaction occur simultaneously. In an aquifer containing complex and heterogeneous flow paths, there can also be exchange between multiple flow networks and between the primary flow paths and background (matrix) pores. If the injection lasts a relatively short time relative to the period of measurement, a plume of tracer will migrate through the aquifer, increasing in size and being reduced in mean concentration with time (Fig. F2B).

Tracer is detected at one or more downstream locations, generating a record of tracer transport versus time $\left(C_{\text {out }}\right)$, known as a "breakthrough curve" (Fig. F2C). The timing of arrival of the downstream record of tracer concentration, as well as the shape of this record, provides information about physical (and potentially chemical and biological) processes in the aquifer. If there were no lateral spreading and mixing and monitoring sites were located immediately downstream from the injection site, all of the tracer mass would be represented in the breakthrough curve. In practice, flow patterns and processes tend to be complex, monitoring points are not located perfectly downstream, and tracer mass recovery is rarely complete. Many tracers behave nonconservatively during transport. In addition, a single period of tracer injection can result in generation of a breakthrough curve having multiple peaks separated in time (Fig. F2B). One interpretation for this kind of result is that tracer is partitioned and transported along distinct primary and secondary flow paths.

Little is known about the actual flow paths of largescale fluid transport in the ocean crust. The crust is often idealized as being a single homogeneous and isotropic hydrologic layer, or one in which properties vary smoothly with depth, but examination of core samples, wireline logs from boreholes, and 
ocean crust in outcrop suggests that flow pathways in the ocean crust are complex (e.g., Bach et al., 2004; Bartetzko, 2005; Gillis and Robinson, 1990; Gillis et al., 2001; Karson, 1998). The Expedition 327 tracer experiment was developed to provide fundamental information on rates and directions of transport, relations between solute and particle transport, the effective porosity of the crust (fraction contributing to the majority of fluid and solute transport), and the nature of connectivity (vertical and horizontal) between boreholes drilled into the extrusive ocean crust. We injected a mixture of solute, gas, and particle tracers (conservative and nonconservative) to assess how transport of these phases might differ. Because this kind of experiment has never been attempted in the ocean crust, simply demonstrating that two sections of the crust are in hydrologic communication across a distance of hundreds of meters and quantifying the time required for molecules of tracer to be transported between the sites would be an important result. This experiment was also developed to take advantage of the operational capabilities of the R/V JOIDES Resolution in conducting a tracer experiment (using existing shipboard systems to the greatest extent possible) and to determine how these capabilities might be modified for future tracer transport studies.

\section{Expedition 327 tracer experiments}

\section{Tracer injection overview}

Tracer injection during Expedition 327 was designed to occur as part of a $24 \mathrm{~h}$ pumping experiment in Hole U1362B, used to assess formation properties at a lateral scale greater than that permitted through more conventional 1-2 $\mathrm{h}$ packer tests (see the "Site U1362" chapter). A drill string packer has been used on the JOIDES Resolution most commonly for shorter term hydrologic testing, but because that tool is subject to deflation in heavy seas and this test was to last much longer than earlier tests, we used a casing running tool to seal the top of $103 / 4$ inch casing in the throat of the reentry cone (Fig. F2D). A stinger made of standard drill pipe was extended from the base of the casing running tool to the end of $103 / 4$ inch casing and was used to direct the tracer injectate into upper basement. Additional downhole seals were installed as part of earlier casing operations between the top of 103/4 and 16 inch casing (swellable packer and a seal sub with an O-ring), 103/4 inch casing and basement (cement), and 16 inch casing and across the sediment/basement interface (cement) (Fisher, Wheat, et al.). The integrity of these seals was verified during the $24 \mathrm{~h}$ pumping experiment by visual inspection of the reentry cone; no plume was seen being emitted during the experiment. Initial inspection of downhole pressure records during injection are also consistent with the hole being fully sealed. Additional confirmation will come from a careful evaluation of pressure records from nearby boreholes (to be recovered in summer 2011).

For several reasons, the tracer mixing and injection system for this experiment was designed to make use of standard shipboard equipment to the greatest extent possible. The pumping rate was planned to be $5-10 \mathrm{~L} / \mathrm{s}$ (enough to generate a measurable pressure signal at distant boreholes), which required injection of $\sim 500 \mathrm{~m}^{3}$ of fluid in $24 \mathrm{~h}$. It would have been prohibitively expensive and complex to build a completely separate tracer mixing and injection system that was compatible with shipboard equipment and capable of handling this pumping rate and total volume. A custom mixing and injection system could have been made cleaner than the shipboard plumbing, but we would still be pumping the fluid through rig hoses and fittings and nearly $3 \mathrm{~km}$ of drill pipe coated with rust, pipe grease, and other contamination. Also, we needed to be able to set and control pumping and injection rates from the rig floor and to hold these rates constant. We planned to use a gas tracer during most of the $24 \mathrm{~h}$ injection period. It is better for gas to be injected under pressure than mixed in an open tank where there could be loss to the atmosphere. We planned to inject solute and particle tracers in short pulses to maximize injectate concentrations, and this required mainly that we introduce the tracer into the drill pipe quickly. To the extent that there is contamination during tracer injection, this can be assessed through analysis of preand postinjection concentrations and comparison of shipboard and downhole samples. As described later, injectate samples were collected on the ship and downhole throughout the injection period, which will allow postcruise analysis of the masses and concentrations of all tracers.

Fluid and tracers were injected using two pumping systems: mud pumps and cement pumps (Fig. F3). Mud pumps are used routinely during coring, hole cleaning, and other downhole operations on the JOIDES Resolution and are located on the lower tween deck, four levels below and slightly aft of the rig floor. Surface seawater is the primary drilling fluid during most operations, but freshwater can be delivered from a holding tank (either filled on shore and transported to sea or generated using the shipboard desalination system). Salt- and freshwater muds are commonly used on the JOIDES Resolution to increase the density and viscosity of the drilling fluid, which can help to circulate cuttings from the hole. Most 
conventional drilling rigs have mud returns to the platform, which allows filtering, collection of cuttings, and reuse of drilling mud through repeated circulation. There is no fluid return system on the JOIDES Resolution, so any drilling mud pumped into the hole flows either into the formation or up and out of the hole at the seafloor. No attempt was made to clean the mud pumps, intake, hoses, or other components prior to the injection test, which followed an extended period of seawater pumping.

The driller operates the mud pumps using a series of rotating switches in the driller's shack adjacent to the rig floor, with separate gauges reporting the total amount of fluid pumped and the current pumping rate in units of strokes and strokes per minute (SPM), respectively. Pumping data are also recorded with the Rig Instrumentation System (RIS), which was configured to collect data at $1 \mathrm{~s}$ intervals during Expedition 327. The JOIDES Resolution's pumps are Oilwell A1700-PT triplex units, each of which has three pistons attached to a crank shaft. The displacement of the pump is equal to liner bore area $\times$ plunger stroke $\times$ number of pistons $\times$ crank shaft revolutions $\times$ pump efficiency. As currently configured, the mud pumps use three $16.5 \mathrm{~cm}$ diameter pistons and liners and have an efficiency of $\sim 95 \%$, such that 1 SPM $=$ 5.2 gallon $/ \mathrm{min}=0.33 \mathrm{~L} / \mathrm{s}$. The pumps generally require operation at a minimum rate of 10-12 SPM (3.3-4.0 L/s), and with both pumps online simultaneously (as during hole cleaning operations during Expedition 327), the typical pumping rate is $80-120$ SPM (26.7-40.1 L/s). Fluid displaced with the mud pumps rises up a standpipe on the aft starboard side of the rig floor and is routed either up the rig and back down through the top drive or through a circulation head and directly into the drill pipe. The former path was used for all tracer injection operations during Expedition 327. A pumping rate of 20 SPM $(6.7 \mathrm{~L} / \mathrm{s})$ was used through most of the $24 \mathrm{~h}$ pumping and tracer injection test. This pumping rate was considered to be great enough to generate a significant single- and cross-hole response in this area (Becker and Fisher, 2000, 2008; Fisher et al., 2008), and faster pumping rates would have contributed to greater tracer dilution prior to introduction of injectate into the borehole.

The JOIDES Resolution's cement pump system (Fig. F3) is used to mix cement that is subsequently injected into the drill pipe at the rig floor using pipes and hoses that are independent of the mud pump system. The cement mixing and pumping system is located on the upper tween deck, one deck up and directly above the mud pumps, three levels below the rig floor. During a normal cementing job, dry cement is added to water, and the mixture is circulated locally until desired properties (density, viscosity, and composition) are achieved, after which the cement is pumped up to the rig floor and injected into the drill pipe. The cement mixing tank is relatively small, so when completing a typical cementing job (20-40 bbl, 3250-6500 L), there is usually a steady inflow of water and dry cement and an outflow of wet cement until the total desired quantity has been pumped. The two cement additive tanks, each having a volume of $10 \mathrm{bbl}$ (420 gallons, $1630 \mathrm{~L}$ ), can be used to dissolve or suspend additional compounds that are added to the cement slurry during mixing and injection. We used these additive tanks to premix soluble salts and fluorescent particles prior to injection as part of the Expedition 327 tracer experiment.

The two cement pumps are controlled from the cement room using a rotating switch, and a gauge in the driller's shack indicates total volume pumped and pumping rate of two separate pumps, also in strokes and SPM. Like the mud pumps, the cement pumps are positive displacement pumps, so fluids injected using this system are added to whatever is being displaced with the mud pumps. The cement pumps have smaller pistons and liners, and the volumetric pump rate conversion is $1 \mathrm{SPM}=1.6$ gallon $/ \mathrm{min}=0.104 \mathrm{~L} / \mathrm{s}$.

Prior to the start of the tracer injection experiment, the cement mixing system was circulated and cleaned with detergent to remove rust and residual cement and mud from the tanks, hoses, and pipes. This system is inherently dirty, and complete cleaning is impossible. Instead, we worked with the rig crew to identify the dirtiest and most accessible parts of the mixing and injection system and to clean these repeatedly to remove the largest potential sources of contamination. Cement mixing tanks were flushed repeatedly between brief periods of solute and particle tracer injection. We collected injectate samples throughout the $24 \mathrm{~h}$ pumping period. During most of this time, no dissolved or particle tracers were added to the injected fluid, which will allow a postcruise assessment of contamination for the tracers used and an assessment of system retention time following the end of injection of each tracer.

Neither the mud pumps nor the cement pumps can be set in advance to pump at a particular rate. Rather, the driller or cement pump operator adjusts a rotating switch to get the pumps started and set an initial rate. The rate is subsequently adjusted by hand until the rig floor gauges show that the desired rate has been achieved. Adjustment typically takes 1-2 min. Both pumps will stall out if the pumping rate is set too low. If a low pumping rate is desired, one must generally set a relatively high initial pump- 
ing rate to get the system started and then reduce the rate and verify that the system continues to run. In addition, separate valves must be shifted to pump freshwater rather than seawater and to add fluid from the cement pump system to the flow of fluid from the mud pumps. All of these activities require careful telephone communication between the rig floor and the mud pump and cement pump rooms, several decks below the rig floor, and this can be complicated by the noise generated when either of these pumping systems is in operation (strong hearing protection is required).

The tracer injection sequence was designed to maximize the initial concentrations of tracers in injectate during the experiment, even though this meant that solute and particulate tracers were injected during periods of only a few minutes. It can be helpful to extend the period of injection to learn more about tracer transport properties, but we opted for a shorter injection period for most tracers because of the cost and difficulty of injecting large quantities of solute and particles for 20-24 h and the extent of anticipated dilution and limits on detection (Table T1). It was much easier to inject the gas tracer for an extended period, as we did, and comparison of results based on longer and shorter periods of tracer injection should be helpful for planning future experiments.

\section{Sulfur hexafluoride $\left(\mathrm{SF}_{6}\right)$ tracer \\ Preparation}

Sulfur hexafluoride $\left(\mathrm{SF}_{6}\right)$ was introduced into fluid being delivered by the mud pumps using a manifold installed in the mud pump room (Figs. F3, F4). The manifold design was based on a system developed for $\mathrm{SF}_{6}$ tracer testing in an aquifer on land (Clark et al., 2005) and was designed to introduce the gas tracer into a backpressured standpipe at a constant rate throughout most of a $24 \mathrm{~h}$ injection period. We knew that the pressure in the standpipe, positioned upstream from the mud pumps that deliver water to the drill pipe, would be relatively constant because this pipe is precharged by a positive displacement pump.

The manifold used two eight-port switching valves, each set to actuate at $30 \mathrm{~s}$ intervals, to deliver $\mathrm{SF}_{6}$ from compressed gas bottles. Each of the switching valves was configured with two coils of stainless steel, $1 / 4$ inch outside diameter (OD) tubing having a nominal coil volume of $20 \mathrm{~mL}$. The switching valves operate by rotating $45^{\circ}$ during each actuation. This opens one tubing coil to the incoming (compressed) gas while the other coil is opened to the outflow line (Fig. F4B). The volume of the coils and the difference between inlet and outlet pressures determines the quantity of gas delivered with each valve actuation. One bottle of $\mathrm{SF}_{6}$ was used at a time, and two switching valves were configured in parallel, with their $30 \mathrm{~s}$ activation times staggered. Check valves on the manifold prevented drilling fluid from flowing back into the gas regulators. Analog and digital pressure gauges installed on the regulators and at different points on the manifold allowed system performance to be checked regularly during injection.

The volume of the tubing coils and associated fittings attached to each eight-port valve was determined by laboratory calibration, as follows. Once the manifold was assembled and tested for leaks, high-pressure air was used to determine tubing coil volumes. A plastic bottle was filled with $1.000 \mathrm{~L}$ of water (measured using a volumetric flask) and then inverted and placed on a ring stand below water level in a bucket. A tube was run from the outlet of the tracer injection manifold into the inverted, submerged bottle, and one of the switching valves was operated while inflowing gas pressure was monitored and the number of actuations was counted. The valve was allowed to operate until most of the water was displaced from the inverted plastic bottle. The bottle was then recovered, and the quantity of water remaining was determined using a graduated cylinder. The difference between the initial and final water volumes was equal to the volume of gas (at standard temperature and pressure [STP] conditions) released by the manifold during the test. This test was repeated three or four times for each valve at four values of differential pressure, allowing generation of calibration curves that relate differential pressure to volume of gas introduced by each valve at STP (Figs. F4, F5).

Just prior to the start of the injection test, the $\mathrm{SF}_{6}$ manifold was installed on a rail in the mud pump room adjacent to the standpipe where the gas would be injected (Fig. F6). Gas was added to the standpipe using a $1 / 4$ inch NPT fitting that has been used in the past for injection of perfluorocarbon tracer (PFT) during coring and other operations (House et al., 2003). An analog gauge is attached to the fitting, and a digital pressure gauge was added early during Expedition 327 , with data recorded automatically by the shipboard RIS. We verified earlier during the expedition that pressure in the standpipe rarely deviated from a precharge pressure of $41-43$ psi during normal operation of the mud pumps with surface seawater across a range of pumping rates from 20 to 120 SPM. 


\section{Tracer injection}

Injection of the $\mathrm{SF}_{6}$ tracer began at pumping test hour 0020 and continued until test hour 2032, when both bottles of $\mathrm{SF}_{6}$ were depleted. Pressures indicated by gauges on the regulators and manifold were monitored continuously and recorded every $15 \mathrm{~min}$, or when a change in conditions occurred, by personnel stationed in the mud pump room. The pressure at the inlet to the gas injection manifold averaged 120.3 psi $( \pm 4.4 \mathrm{psi}, 1 \sigma)$ during the period of $\mathrm{SF}_{6}$ gas injection, the mean backpressure in the standpipe during this time was 40.9 psi ( $\pm 1.8 \mathrm{psi})$, and the mean differential pressure was 79.5 psi $( \pm 6.1$ psi). Calibration of the $\mathrm{SF}_{6}$ injection manifold (Fig. F5), with two valves operating every $30 \mathrm{~s}$ and a mean coil volume for both valves of $21.8 \mathrm{~mL}$, indicates a mean $\mathrm{SF}_{6}$ injection rate of $0.0192 \mathrm{~mol} / \mathrm{min}$.

Pressure differences between the $\mathrm{SF}_{6}$ manifold and the standpipe varied somewhat when the water source was switched from seawater to freshwater and when additional tracers were added with the cement pump, but these deviations lasted just a few minutes and had little influence on the mass or molar rate of $\mathrm{SF}_{6}$ injection. Given the mean pumping rate during $\mathrm{SF}_{6}$ injection of $6.68 \mathrm{~L} / \mathrm{s}$, the typical injectate concentration during this time was $47.6 \mu \mathrm{M}$, and 23.3 mol of $\mathrm{SF}_{6}$ was injected into the formation in total. The high concentration and rapid rate of $\mathrm{SF}_{6}$ injection meant that much of the gas tracer was likely to be in the form of small bubbles initially, but these bubbles occupied $<0.1 \%$ of the flow generated by the mud pumps. $\mathrm{SF}_{6}$ gas liquefies at relatively low pressures. Any bubbles transported below $\sim 200 \mathrm{~m}$ water depth $(>2 \mathrm{MPa}$ ) should have condensed into small droplets and dissolved during transport (Watson et al., 1988). The drill pipe is a highly efficient heat exchanger, and the high pressure and low temperature of bottom water $\left(26 \mathrm{MPa}\right.$ and $2^{\circ} \mathrm{C}$, respectively), combined with the turbulent flow within the pipe, assured that $\mathrm{SF}_{6}$ was dissolved in solution before it was introduced to the open hole at depth.

\section{Fluorescent particles}

\section{Preparation}

Two kinds of fluorescent particle (colloid) materials were prepared for use during the Expedition 327 tracer experiment: microspheres and stained bacteria. Microspheres having distinct characteristics were acquired from Polysciences, Inc., and mixed in the cement additive tanks prior to injection (Tables T1, T2; Figs. F3, F7). Microspheres were composed of polystyrene tagged with BB Coumarin or YG Fluorescein dyes, compounds that fluoresce at specific wavelengths, and had diameters of $0.5-1.1 \mu \mathrm{m}$ (Ta- ble T2). Microspheres and fluorescent compounds were selected to avoid misidentification of microspheres commonly employed on the JOIDES Resolution for contamination studies during coring operations $(0.5 \mu \mathrm{m}, \mathrm{YG}$ Fluorescein dye). The total stock volume of microspheres injected during the experiment was $700 \mathrm{~mL}$, comprising $\sim 6 \times 10^{13}$ microspheres in suspension. Microspheres have a characteristic density of $990-1010 \mathrm{~kg} / \mathrm{m}^{3}$, slightly lower than seawater, so they should remain suspended during mixing and transport.

Fluorescent-stained microorganisms were injected separately. A natural population of surface microorganisms (along with other colloids) was concentrated from $100 \mathrm{~L}$ of $63 \mu \mathrm{m}$ screened surface seawater into a $2 \mathrm{~L}$ solution using a standard $0.16 \mu \mathrm{m}$ nominal pore-size Tangential Flow Filtration (TFF) system (Pall, Inc.). The concentrated microbes and colloids were fixed in $0.5 \%$ (final) formaldehyde and stained with the DNA-specific fluorochrome 4',6-diamidino2-phenylindole (DAPI) at $5 \mu \mathrm{M}$ (final concentration) (following procedures described by Harvey et al., 1989). On the basis of a separate determination of the concentration of microorganisms in surface seawater in this part of the northeastern Pacific Ocean (Sherr et al., 2001), we estimate that $\sim 10^{11}$ stained cells were injected during this experiment.

\section{Injection}

Microspheres were diluted initially in deionized water and then circulated within the cement mixing system in freshwater prior to injection. Injection was completed during hours 2013-2019 of the pumping test, near the start of a $1 \mathrm{~h}$ period of freshwater injection, with fluid from the cement mixing system being added at $\sim 6.3 \mathrm{~L} / \mathrm{s}$ to the flow from the mud pumps. Microspheres were mixed and injected in freshwater to minimize clumping in suspension. The resulting concentration of microspheres in fluid pumped down the drill pipe and into the formation was $\sim 3 \times 10^{7}$ microspheres $/ \mathrm{mL}$ of injectate.

Stained bacteria were also mixed and circulated in the cement additive tanks prior to injection, but with surface seawater rather than freshwater. The microbes and colloids were injected using the cement pumps at a mean rate of $3.4 \mathrm{~L} / \mathrm{s}$ (added to flow generated with the mud pumps) during hours 2115-2122 of the pumping experiment. Based on the total quantity of fluid injected during this time, the mean concentration of DAPI-stained cells was $\sim 10^{4}$ cells $/ \mathrm{mL}$, well below DAPI's threshold staining concentration. A more reliable estimate of stained microbe concentrations will be based on shipboard sampling and shore-based analysis of injectate, as described later. 


\section{Metal salt tracers}

Metal salt tracers cesium chloride ( $\mathrm{CsCl}$ ), erbium chloride hexahydrate $\left(\mathrm{ErCl}_{3} \cdot 6 \mathrm{H}_{2} \mathrm{O}\right)$, and holmium chloride hexahydrate $\left(\mathrm{HoCl}_{3} \cdot 6 \mathrm{H}_{2} \mathrm{O}\right)$ were injected in two batches. Both batches included an alkali metal (Cs) and one of two lanthanide rare earth metals (Er and Ho). These salts were selected because of their relatively low concentrations in seawater and low detection limits using standard analytical techniques. We expect that these metals may behave nonconservatively during injection and transport and plan to assess this behavior through comparison to the behavior of $\mathrm{SF}_{6}$.

$\mathrm{CsCl}$ was prepared in two injection batches of $15 \mathrm{~kg}$ each $(2 \times 89.1 \mathrm{~mol}$ of $\mathrm{Cs})$, the first mixed in solution with $23 \mathrm{~kg}$ of $\mathrm{ErCl}_{3} \cdot 6 \mathrm{H}_{2} \mathrm{O}(60.3 \mathrm{~mol}$ of $\mathrm{Er})$ and the second mixed with $23 \mathrm{~kg}$ of $\mathrm{HoCl}_{3} \cdot 6 \mathrm{H}_{2} \mathrm{O}(60.6 \mathrm{~mol}$ of Ho). These metal salts were dissolved with seawater initially in 5 gallon buckets (Fig. F7). This salt brine was added to salt water in the cement additive tanks $(\sim 10 \mathrm{bbl}, 1590 \mathrm{~L})$ and then circulated internally until this fluid was introduced with the cement pumps into the flow coming from the mud pumps. The first batch of trace metal tracers was introduced during pumping hours $0301-0308$ at $4.3 \mathrm{~L} / \mathrm{s}$, and the second batch was introduced during pumping hours 19001908 at $5.3 \mathrm{~L} / \mathrm{s}$. The quantity of metal salts added and the overall pumping rate indicate that concentrations of Cs, Er, and Ho were $\sim 10-18 \mu \mathrm{M}$ during injection (Table T1). A more accurate assessment of salt tracer concentrations in injectate will be completed on the basis of shipboard and downhole sampling.

\section{Freshwater}

Freshwater was pumped into the borehole at $6.7 \mathrm{~L} / \mathrm{s}$ during two $1 \mathrm{~h}$ periods (pumping hours 0058-0158 and 1959-2058), resulting in a total volume of freshwater injected of 48,000 L. This is a small fraction of the total amount of surface seawater that was pumped and that flowed independently into the formation during drilling and other Expedition 327 operations. Freshwater could be a useful tracer through measurements of chlorinity, which is relatively easy to measure and has a precision of $0.2 \%$ for seawater values. The freshwater pumped during Expedition 327 was not pure deionized water, and we have assumed for initial calculations that the total salt content of this water was $200 \mathrm{mg} / \mathrm{L}$. We pumped freshwater during two intervals primarily to generate large changes in fluid chemistry that occurred at known times and could serve as time stamps for calibration for the pumping rate of downhole samplers deployed during tracer injection. This sampling system is discussed in the next section of this paper.

\section{Tracer monitoring}

\section{Rig floor sampling of injectate}

Although quantities of tracers mixed and added to fluids pumped into the formation were known in advance, additional steps were taken to verify tracer concentrations as the injectate passed across the rig floor and through the end of the stinger before entering the formation. Collection of samples in these locations was important for verifying the extent and variability of mixing that could occur between the mud and cement pumps and the rig floor and because we could not know in advance if there might be difficulties with system leaks or maintaining consistent flow rates. In addition, we wished to evaluate the potential influence of changing injectate chemistry (salt water versus freshwater and brine concentration) on the gas, solute, and particle tracers as mixed on the ship and injected into the formation.

A sampling station was established just prior to beginning the pumping experiment on the starboard side of the rig floor for collection of injectate (Fig. F8). A stainless steel needle valve was installed on a hammer union connected to a rig floor standpipe, and a $1 / 4$ inch OD stainless steel line was run from this valve. The hammer union and needle valve were positioned just upstream from where the standpipe directs pumped water up the rig and back down through the top drive to the drill pipe. Inflow of fluid from the cement pumps was rerouted so that mixing would occur before the fluid passed the sampling point. Fluid passing down the sample line was directed through a three-way valve to a syringe needle attached to a Luer-Lok fitting or through an open-ended section of fiber-reinforced flexible tubing. Additional ball and needle valves were added to ensure that the sampling lines were sealed when not in use and that flow could be controlled by those collecting injectate samples.

A pretest evaluation of system pressures demonstrated that fluid in the standpipe was expected to remain $<100$ psi throughout the injection test, and the needle valve installed at the hammer union could be adjusted to reduce the pressure of fluid in the sampling tubing if needed. In general, the fluid sampling pressure remained $<10 \mathrm{psi}$, but there were brief periods of higher pressures on the rig floor during the experiment.

$\mathrm{SF}_{6}$ gas sampling on the rig was accomplished using standard methods and two kinds of containers: glass vacutainers and copper tubes (Clark et al., 2004). Vacutainers were sealed with rubber septa, without additives, and were evacuated prior to the experiment. Just before each sample was collected the syringe needle was elevated, and air in the line and needle 
was pushed out by the flow of injectate, aided by tapping the side of the line, fittings, and needle. While injectate continued to flow, the needle was pushed quickly through the septum of a prelabeled vacutainer and then withdrawn rapidly when the vacutainer was full. Vactuainer samples were collected every $\sim 30 \mathrm{~min}$. Copper tubing samples were collected by attaching the end of the fiber-reinforced tubing to a piece of precut and prelabeled copper tubing (6.4 $\mathrm{mm}$ inside diameter [ID]), allowing the injectate to flow freely. The far end of the copper tubing was elevated to allow air to escape while injectate flowed out of the tube, and when fluid had flowed freely for several seconds, clamps on both ends of the copper tubing were tightened to make a cold weld (crimp). Copper tube samples were collected every 1-2 $\mathrm{h}$.

Fluid samples to monitor inputs of metals salts and freshwater were collected at $\sim 30$ min intervals in prelabeled, $25 \mathrm{~mL}$ high-density polyethylene (HDPE) bottles that were acid washed in $2 \mathrm{M} \mathrm{HNO}_{3}$ prior to use. Injectate was used to rinse the bottles and caps three times before a sample was collected. The periods of salt addition were relatively brief, and we generally attempted to collect two samples during the time of peak concentration for salt tracers. Collection of salt- and freshwater samples throughout the experiment will help with assessment of contamination as these materials pass through mixing systems and pipes.

Rig floor samples for fluorescent microspheres, stained bacteria, and general microbiological analyses were collected in additional prelabeled containers at specific times of interest throughout tracer injection. Background samples were collected at 30 min intervals for several hours prior to fluorescent particle injection, at intervals of 2-3 min during the brief periods of particle injection, and then at 10-30 min intervals following particle injection. These samples were collected in acid-washed and sterilized prelabeled HDPE bottles and centrifuge tubes.

\section{Stinger sampling of injectate}

A specialized downhole sampling and pressure monitoring system was designed and constructed for use during the tracer experiment (Fig. F8). The system was housed in a $\sim 6.5 \mathrm{~m}$ long piece of $6 \% 8$ inch OD pipe, which was deployed at the end of the stinger. The upper end of this pipe housed a fluid sampler carrier, which was used to collect injectate continuously as it flowed out through slots near the end of the pipe. The pipe also housed a pair of Micro-Smart pressure gauges (model HT-750SN, 0-10,000 psi absolute) that were placed in a chamber below the fluid sampler carrier (Figs. F2, F8). The pressure gauges were isolated from direct contact with fluid flowing out of the pipe and into the formation to reduce noise associated with turbulent flow, but they were exposed to formation pressure through holes in the side of the carrier.

Because we wished to collect fluid samples at a rate much greater than that possible using the continuous fluid sampling systems deployed on or in CORKs (typically 1-2 mL/week), specialized reverse-osmosis (RO) pumps were developed specifically for this application (Wheat et al.). These pumps were designed to recover $1-2 \mathrm{~mL} / \mathrm{h}$ in $1.2 \mathrm{~mm}$ ID tubing at temperature and pressure conditions anticipated at depth during tracer injection $\left(2^{\circ} \mathrm{C}\right.$ and $26 \mathrm{MPa}$, respectively). The actual RO pump rate during tracer injection will be evaluated on the basis of samples collected. Because the concentrations of tracers in the injectate are so high (Table T1), $0.5 \mathrm{~mL}$ sample sizes should be sufficient for analysis after being diluted by several orders of magnitude.

The downhole sampler included four complete RO pump and sample coil systems (Fig. F8). Two of the systems had sample coils composed of polytetrafluroethylene (PTFE), and the other two were made of copper. Fluids collected in the PTFE coils will be used for analysis of trace metals and chlorinity. Copper tubing was used for fluids collected for analysis of dissolved $\mathrm{SF}_{6}$ gas because PTFE is permeable to gases. Intakes for all sample coils were located at the lower end of the RO sampler carrier, which was installed inside the $6 \% 8$ inch pipe just before the stinger was submerged in the moonpool (Fig. F8). After completion of the pumping and tracer injection experiment, the sampler carrier was recovered and sample coils were removed. Subsamples from the PTFE tubing were extracted immediately in splits of $0.44 \mathrm{~mL}$ (40 cm tubing lengths), and injected into acidcleaned $0.5 \mathrm{~mL}$ centrifuge tubes. The ends of the copper coils were crimped before being shipped to shore for extraction and analysis of dissolved $\mathrm{SF}_{6}$.

\section{Tracer monitoring with downhole and wellhead sampling}

Autonomous fluid sampling systems were operating in and on existing long-term CORKs in Holes U1301A, U1301B, U1362A, and 1026B (Fisher, Wheat, et al.) before tracer injection began in Hole U1362B. An additional CORK was deployed in Hole U1362B after the tracer injection period. Downhole OsmoSamplers were deployed on CORKs installed in Holes U1362A and U1362B during Expedition 327. Wellhead samplers (drawing fluids from stainless steel lines sampling from upper basement) will be attached to these CORKs in summer 2011. In addition, 
a "GeoMICROBE" sampling sled (Wheat et al.) was deployed in Hole U1301A during R/V Atlantis expedition AT15-66 (using remotely operated vehicle [ROV] Jason) a few weeks prior to the start of Expedition 327. This system is connected to a fluid sample line that terminates in a screen in uppermost basement ( 271 meters below seafloor; 11 meters subbasement) and will collect twice-monthly samples, alternately $500 \mathrm{~mL}$ (whole fluids) and $8000 \mathrm{~mL}$ (in situ filtrations). Samples from this system will also be recovered in summer 2011, and additional CORK servicing is planned for summer 2012 to download data and collect fluid samples.

\section{Summary of Expedition 327 tracer injection operations}

The sequence of pumping and tracer injection operations is summarized with plots that show the timing of pumping and tracer addition operations (Fig. F9). The $24 \mathrm{~h}$ pumping experiment began after a $1 \mathrm{~h}$ period of monitoring to establish a pressure baseline following landing of the casing running tool, which positioned the end of the stinger just at the end of $103 / 4$ inch casing, near the top of the open basement interval. The mud pumps were set to inject fluid at 20 SPM $(6.7 \mathrm{~L} / \mathrm{s})$, and this flow rate was held virtually constant throughout the next $24 \mathrm{~h}$. The total pumping rate into the formation reached 11.3-13.4 L/s for four brief periods of 6-8 min each, when salt and fluorescent tracers were added to the injectate using the cement pumps (Fig. F9A).

The primary injectate fluid was surface seawater, but there were two $1 \mathrm{~h}$ periods during which fresh (drill) water was injected. We pumped freshwater during these times to establish easily identifiable changes in bulk water composition that can be used to determine the rate of downhole injectate collection with the RO fluid samplers (Fig. F9B). In addition, the switch from salt- to freshwater and back again might be useful as a single- or cross-hole tracer, although sensitivity to this change is likely to be less than that provided by gas, metal salt, and particle tracers because of dilution during transport (Table T1). The actual salinity of the freshwater injected during pumping hours 0100-0200 and 2000-2100 will be determined by postcruise analysis of injectate samples collected at the rig floor and downhole, as will the elevated salinity during brief periods of salt tracer injection.

The $\mathrm{SF}_{6}$ gas injection rate was held relatively constant during the injection experiment, so the gas concentration should vary mainly during brief periods when the overall pumping rate increased be- cause the cement pumps were turned on (Fig. F8B). During these brief periods, the dissolved $\mathrm{SF}_{6}$ concentration in the injectate should have been reduced. During the first period of salt tracer injection, we attempted to compensate for the increase in fluid pumping rate by raising the differential pressure on the $\mathrm{SF}_{6}$ gas regulator, but this was impractical because of difficulties in determining and maintaining the total fluid flow rate in real time. In fact, the $24 \mathrm{~h}$ injection period is likely to appear much like a single pulse injection when tracer is detected at other boreholes weeks to years after Expedition 327, so there is likely to be little practical benefit in making microadjustments to tracer injection rates based on shortterm changes in fluid injection rates.

The total quantities and concentrations of fluorescent microspheres and microbes injected during the experiment are known to within an order of magnitude, but we will analyze injectate samples collected both at the rig floor and downhole to improve our understanding of how these tracers were introduced to the subseafloor environment. Particulate samples could have clumped during mixing and injection, and concentrations and total masses could have been reduced during passage of the tracers down the drill pipe because of dilution and interactions with pipe grease. One goal of the Expedition 327 experiment was to learn how the addition of tracers to water pumped into the formation influences shipboard operations and to assess how operations and tracer injection systems might be modified in the future to improve similar experiments. A preliminary assessment of project success may be available following CORK servicing activities in summer 2011, when the first subseafloor samples are recovered and analyzed and the first estimates of solute and particle transport rates based on tracer injection are completed.

As of the end of Expedition 327, there is a network of six long-term CORKs monitoring pressure or fluid compositional responses to both the $24 \mathrm{~h}$ pumping experiment run during Expedition 327 and a longterm cross-hole experiment that will begin in summer 2011 (Fig. F10) (Fisher, Wheat, et al.). The longterm experiment will be run by installing a flowmeter and opening of a large-diameter ball valve on the wellhead of the CORK in Hole U1362B, the same hole that was used for tracer injection during Expedition 327. This will allow formation fluids to discharge at 5-10 L/s from Hole U1362B, which could cause tracers that previously migrated away from Hole U1362B to flow back toward this observatory. Fluid samplers installed on the wellheads and at depth in Holes 1026B, U1301A, U1301B, U1362A, and U1362B will collect samples for evaluation of tracer concentrations in borehole fluids from these 
holes. These holes are aligned in a direction $\left(\mathrm{N} 20^{\circ} \mathrm{E}\right)$ that is parallel to the structural strike of basement in this area.

Hole $1027 \mathrm{C}$ is oriented at an azimuth of $\mathrm{N} 95^{\circ} \mathrm{E}$ and located $2.3 \mathrm{~km}$ from Hole U1362B. Because Expedition 327 researchers were not able to recover the first-generation CORK in Hole 1027C, deepen the hole, or install a new observatory system (see the "Site 1027" chapter), there is presently no fluid sampling in Hole 1027C. This is unfortunate, but if the dominant flow direction in basement in this area is oriented along structural strike (Fisher et al., 2003, 2008; Hutnak et al., 2006; Wheat et al., 2000), then it is unlikely that tracers injected in Hole U1362B would be detected in Hole 1027C. Researchers are preparing to retrofit the Hole 1027C CORK wellhead for continued monitoring of pressure during ROV operations in summer 2011, and it may be possible to install a fitting that will also permit borehole fluid sampling in this hole in the future. This would allow monitoring during a later period of the current tracer experiment (or as part of a future tracer experiment) to test the hypothesis that there is relatively little advection of solutes or particles in a direction oblique to that favored by the structural trend of regional basement.

\section{Acknowledgments}

We are grateful for the advice and assistance provided by Steve Midgley, Mike Storms, Tom Pettigrew, Phil Christie, Joe (Bubba) Attryde, Charlie Watts, Nick Parrish, Cecil (Jardin) Jones, and Wayne Malone in configuring and operating tracer injection and sampling systems during Expedition 327. Bill Mills, Mike Meiring, Eric Jackson, Kristin Hillis, Randy Gjesvold, Kevin Grigar, Garrick Van Rensburg, Dustin Winslow, Dean Ferrell, Lisa Crowder, Tim Bronk, Lisa Brandt, Tim Fulton, Bob Aduddell, Stefan Mrozewski, Takeshi Tsuji, Katie Inderbitzen, Katerina Petronotis, Chris Bennight, Amanda Turner, and Thomas Gorgas assisted with the configuration of the tracer injection and sampling systems and were essential in the collection of RIS data and rig floor injectate samples. Planning and construction of injection and sampling systems was supported by US National Science Foundation grants OCE-0550713 and OCE-0727952 (AF), OCE-0549910 and OCE-0726838 (JPC), OCE-0727119 (CGW), and OCE-0550203 and OCE-0726563 (JFC). Elizabeth Screaton and Evan Solomon provided careful reviews that helped clarify the presentation in this paper. This is contribution number 102 from the Center for Dark Energy Biosphere Investigations.

\section{References}

Altman, S.J., Meigs, L.C., Dones, T.L., and McKenna, S.A., 2002. Controls of mass recovery rates in single-well injection-withdrawal tracer tests with a single-porosity, heterogeneous conceptualization. Water Resour. Res., 38:1125. doi:10.1029/2000WR000182

Bach, W., Humphris, S.E., and Fisher, A.T., 2004. Fluid flow and fluid-rock interaction within ocean crust: reconciling geochemical, geological, and geophysical observations. In Wilcock, W.S.D., Delong, E.F., Kelley, D.S., Baross, J.A., and Cary, C.S. (Eds.), The Subseafloor Biosphere at Mid-Ocean Ridges. Geophys. Monogr., 144:99_ 118.

Bartetzko, A., 2005. Effect of hydrothermal ridge flank alteration on the in situ physical properties of uppermost oceanic crust. J. Geophys. Res., [Solid Earth], 110(B6):B06203-B06211. doi:10.1029/2004JB003228

Becker, K., and Fisher, A.T., 2000. Permeability of upper oceanic basement on the eastern flank of the Juan de Fuca Ridge determined with drill-string packer experiments. J. Geophys. Res., [Solid Earth], 105(B1):897-912. doi:10.1029/1999JB900250

Becker, K., and Fisher, A.T., 2008. Borehole packer tests at multiple depths resolve distinct hydrologic intervals in 3.5-Ma upper oceanic crust on the eastern flank of Juan de Fuca Ridge. J. Geophys. Res., [Solid Earth], 113(B7):B07105. doi:10.1029/2007JB005446

Becker, M.W., Metge, D.W., Collins, S.A., Shapiro, A.M., and Harvey, R.W., 2003. Bacterial transport experiments in fractured crystalline bedrock. Ground Water, 41(5):682-689. doi:10.1111/j.17456584.2003.tb02406.x

Birk, S., Geyer, T., Liedl, R., and Sauter, M., 2005. Processbased interpretation of tracer tests in carbonate aquifers. Ground Water, 43(3):381-388. doi:10.1111/j.17456584.2005.0033. $\mathrm{x}$

Brouyère, S., Carabin, G., and Dassargues, A., 2005. Influence of injection conditions on field tracer experiments. Ground Water, 43(3):389-400. doi:10.1111/j.17456584.2005.0041.X

Clark, J.F., Hudson, G.B., and Avisar, D., 2005. Gas transport below artificial recharge ponds: insights from dissolved noble gases and a dual gas $\left(\mathrm{SF}_{6}\right.$ and $\left.{ }^{3} \mathrm{He}\right)$ tracer experiment. Environ. Sci. Technol., 39(11):3939-3945. doi:10.1021/es049053x

Clark, J.F., Hudson, G.B., Davisson, M.L., Woodside, G., and Herndon, R., 2004. Geochemical imaging of flow near an artificial recharge facility, Orange County, California. Ground Water, 42(2):167-174. doi:10.1111/ j.1745-6584.2004.tb02665.x

Dann, R.L., Close, M.E., Pang, L., Flintoft, M.J., and Hector, R.P., 2008. Complementary use of tracer and pumping tests to characterize a heterogeneous channelized aquifer system in New Zealand. Hydrogeol. J., 16(6):11771191. doi:10.1007/s10040-008-0291-4

Day-Lewis, F.D., Lane, J.W., and Gorelick, S.M., 2006. Combined interpretation of radar, hydraulic, and tracer data from a fractured-rock aquifer near Mirror Lake, New 
Hampshire, USA. Hydrogeol. J., 14(1-2):1-14. doi:10.1007/s10040-004-0372-y

Elderfield, H., Wheat, C.G., Mottl, M.J., Monnin, C., and Spiro, B., 1999. Fluid and geochemical transport through oceanic crust: a transect across the eastern flank of the Juan de Fuca Ridge. Earth Planet. Sci. Lett., 172(1-2):151-165. doi:10.1016/S0012821X(99)00191-0

Fisher, A.T., Davis, E.E., and Becker, K., 2008. Borehole-toborehole hydrologic response across $2.4 \mathrm{~km}$ in the upper oceanic crust: implications for crustal-scale properties. J. Geophys. Res., [Solid Earth], 113(B7):B07106. doi:10.1029/2007JB005447

Fisher, A.T., Davis, E.E., Hutnak, M., Spiess, V., Zühlsdorff, L., Cherkaoui, A., Christiansen, L., Edwards, K., Macdonald, R., Villinger, H., Mottl, M.J., Wheat, C.G., and Becker, K., 2003. Hydrothermal recharge and discharge across $50 \mathrm{~km}$ guided by seamounts on a young ridge flank. Nature (London, U. K.), 421(6923):618-621. doi:10.1038/nature01352

Fisher, A.T., Wheat, C.G., Becker, K., Davis, E.E., Jannasch, H., Schroeder, D., Dixon, R., Pettigrew, T.L., Meldrum, R., McDonald, R., Nielsen, M., Fisk, M., Cowen, J., Bach, W., and Edwards, K., 2005. Scientific and technical design and deployment of long-term subseafloor observatories for hydrogeologic and related experiments, IODP Expedition 301, eastern flank of Juan de Fuca Ridge. In Fisher, A.T., Urabe, T., Klaus, A., and the Expedition 301 Scientists, Proc. IODP, 301: College Station, TX (Integrated Ocean Drilling Program Management International, Inc.). doi:10.2204/

iodp.proc.301.103.2005

Gillis, K.M., Muehlenbachs, K., Stewart, M., Gleeson, T., and Karson, J., 2001. Fluid flow patterns in fast spreading East Pacific Rise crust exposed at Hess Deep. J. Geophys. Res., [Solid Earth], 106(B11):26311-26329. doi:10.1029/2000JB000038

Gillis, K.M., and Robinson, P.T., 1990. Patterns and processes of alteration in the lavas and dykes of the Troodos ophiolite, Cyprus. J. Geophys. Res., [Solid Earth], 95(B13):21523-21548. doi:10.1029/JB095iB13p21523

Göppert, N., and Goldscheider, N., 2008. Solute and colloid transport in karst conduits under low- and highflow conditions. Ground Water, 46(1):61-68. doi:10.1111/j.1745-6584.2007.00373.x

Haggerty, R., Fleming, S.W., Meigs, L.C., and McKenna, S.A., 2001. Tracer tests in a fractured dolomite: 2 . Analysis of mass transfer in single-well injection-withdrawal tests. Water Resour. Res., 37(5):1129-1142. doi:10.1029/ 2000WR900334

Hall, S.H., Luttrell, S.P., and Cronin, W.E., 1991. A method for estimating effective porosity and ground-water velocity. Ground Water, 29(2):171-174. doi:10.1111/ j.1745-6584.1991.tb00506.x

Harvey, R.W., George, L.H., Smith, R.L., and LeBlanc, D.R., 1989. Transport of microspheres and indigenous bacteria through a sandy aquifer: results of natural- and forced-gradient tracer experiments. Environ. Sci. Technol., 23(1):51-56. doi:10.1021/es00178a005
House, C.H., Cragg, B.A., Teske, A., and the Leg 201 Scientific Party, 2003. Drilling contamination tests during ODP Leg 201 using chemical and particulate tracers. In D'Hondt, S.L., Jørgensen, B.B., Miller, D.J., et al., Proc. ODP, Init. Repts., 201: College Station, TX (Ocean Drilling Program), 1-19. doi:10.2973/ odp.proc.ir.201.102.2003

Hulme, S.M., Wheat, C.G., Coggon, R.M., and McManus, J., 2008. Data report: trace element, $\mathrm{Sr}$ isotope, and Ge/ Si composition of fluids and sediments in ridge-flank low-temperature hydrothermal environments. In Fisher, A.T., Urabe, T., Klaus, A., and the Expedition 301 Scientists, Proc. IODP, 301: College Station, TX (Integrated Ocean Drilling Program Management International, Inc.). doi:10.2204/iodp.proc.301.202.2008

Hutnak, M., Fisher, A.T., Zühlsdorff, L., Spiess, V., Stauffer, P.H., and Gable, C.W., 2006. Hydrothermal recharge and discharge guided by basement outcrops on 0.7-3.6 Ma seafloor east of the Juan de Fuca Ridge: observations and numerical models. Geochem., Geophys., Geosyst., 7(7):Q07O02. doi:10.1029/2006GC001242

Karson, J.A., 1998. Internal structure of oceanic lithosphere: a perspective from tectonic windows. In Buck, W.R., Delaney, P.T., Karson, J.A., and Lagabrielle, Y. (Eds.), Faulting and Magmatism at Mid-Ocean Ridges. Washington, DC (Am. Geophys. Union), 177-218.

Khaleel, R., 1989. Scale dependence of continuum models for fractured basalts. Water Resour. Res., 25(8):18471855. doi:10.1029/WR025i008p01847

Leap, D.I., and Kaplan, P.G., 1988. A single-well tracing method for estimating regional advective velocity in a confined aquifer: theory and preliminary laboratory verification. Water Resour. Res., 24(7):993-998. doi:10.1029/WR024i007p00993

Lilley, M.D., Butterfield, D.A., Olson, E.J., Lupton, J.E., Macko, S.A., and McDuff, R.E., 1993. Anomalous $\mathrm{CH}_{4}$ and $\mathrm{NH}_{4}{ }^{+}$concentrations at an unsedimented midocean-ridge hydrothermal system. Nature (London, $U$. K.), 364(6432):45-47. doi:10.1038/364045a0

Mottl, M.J., and Gieskes, J.M., 1990. Chemistry of waters sampled from oceanic basement boreholes, 1979-1988. J. Geophys. Res., 95:9327-9342.

Mottl, M.J., and Wheat, C.G., 1994. Hydrothermal circulation through mid-ocean ridge flanks: fluxes of heat and magnesium. Geochim. Cosmochim. Acta, 58(10):22252237. doi:10.1016/0016-7037(94)90007-8

Neuman, S.P., 2005. Trends, prospects and challenges in quantifying flow and transport through fractured rocks. Hydrogeol. J., 13(1):124-147. doi:10.1007/s10040-0040397-2

Niemann, W.L., and Rovey, C.W., II, 2009. A systematic field-based testing program of hydraulic conductivity and dispersivity over a range in scale. Hydrogeol. J., 17(2):307-320. doi:10.1007/s10040-008-0365-3

Novakowski, K.S., Lapcevic, P.A., Voralek, J., and Bickerton, G., 1995. Preliminary interpretation of tracer experiments conducted in a discrete rock fracture under conditions of natural flow. Geophys. Res. Lett., 22(11):14171420. doi:10.1029/95GL00569 
Novakowski, K.S., Lapcevic, P.A., Voralek, J.W., and Sudicky, E.A., 1998. A note on a method for measuring the transport properties of a formation using a single well. Water Resour. Res., 34(5):1351-1356. doi:10.1029/ 98WR00292

Sherr, E.B., Sherr, B.F., and Cowles, T.J., 2001. Mesoscale variability in bacterial activity in the northeast Pacific Ocean off Oregon, USA. Aquat. Microb. Ecol., 25:21-30. doi:10.3354/ame025021

Solomon, E.A., Kastner, M., Wheat, C.G., Jannasch, H., Robertson, G., Davis, E.E., and Morris, J.D., 2009. Longterm hydrogeochemical records in the oceanic basement and forearc prism at the Costa Rica subduction zone. Earth Planet. Sci. Lett., 282(1-4):240-251. doi:10.1016/j.epsl.2009.03.022

Walker, B.D., McCarthy, M.D., Fisher, A.T., and Guilderson, T.P., 2007. Dissolved inorganic carbon isotopic composition of low-temperature axial and ridge-flank hydrothermal fluids of the Juan de Fuca Ridge. Mar. Chem., 108(1-2):123-136. doi:10.1016/ j.marchem.2007.11.002

Watson, A.J., Ledwell, J.R., Webb, D.J., and Wunsch, C., 1988. Purposefully released tracers (and discussion). Philos. Trans. R. Soc., A, 325(1583):189-200. doi:10.1098/ rsta.1988.0051

Wheat, C.G., Elderfield, H., Mottl, M.J., and Monnin, C., 2000. Chemical composition of basement fluids within an oceanic ridge flank: implications for along-strike and across-strike hydrothermal circulation. J. Geophys. Res., [Solid Earth], 105(B6):13437-13447. doi:10.1029/ 2000JB900070

Wheat, C.G., Jannasch, H.W., Fisher, A.T., Becker, K., Sharkey, J., and Hulme, S., 2010. Subseafloor seawaterbasalt-microbe reactions: continuous sampling of borehole fluids in a ridge flank environment. Geochem., Geophys., Geosyst., 11(7):Q07011. doi:10.1029/ 2010GC003057

Wheat, C.G., Jannasch, H.W., Kastner, M., Plant, J.N., and DeCarlo, E.H., 2003. Seawater transport and reaction in upper oceanic basaltic basement: chemical data from continuous monitoring of sealed boreholes in a ridge flank environment. Earth Planet. Sci. Lett., 216(4):549564. doi:10.1016/S0012-821X(03)00549-1

Wheat, C.G., and McDuff, R.E., 1995. Mapping the fluid flow of the Mariana Mounds ridge flank hydrothermal system: pore water chemical tracers. J. Geophys. Res., [Solid Earth], 100(B5):8115-8131. doi:10.1029/ 95JB00047

Initial receipt: 18 November 2010

Acceptance: 15 March 2011

Publication: 5 September 2011

MS 327-108 
Figure F1. Bathymetric map illustrating locations of borehole observatories for cross-hole tracer experiment. Inset shows regional setting, with area of main figure shown by blue rectangle. Contour interval $=10 \mathrm{~m}$, gold contours = basement outcrops. Tracer injection during Expedition 327 occurred in Hole U1362B. Monitoring for tracer arrival is occurring with automated samplers integrated with CORK observatories in Holes U1301A, U1301B, U1362A, and 1026B and in Hole U1362B, where tracers were injected. Blue dashed arrows = general direction of inferred fluid flow in basement, based on geochemical, geothermal, and numerical modeling studies (e.g., Wheat et al., 2000; Fisher et al., 2003; Hutnak et al., 2006; Walker et al., 2007). Hole 1027C was intended to be configured as an additional monitoring point for the tracer experiment, but Expedition 327 was not able to recover and replace the old observatory (see the "Site 1027" chapter). An attempt will be made to retrofit the old observatory for pressure monitoring and fluid sampling during a summer 2011 CORK servicing expedition.

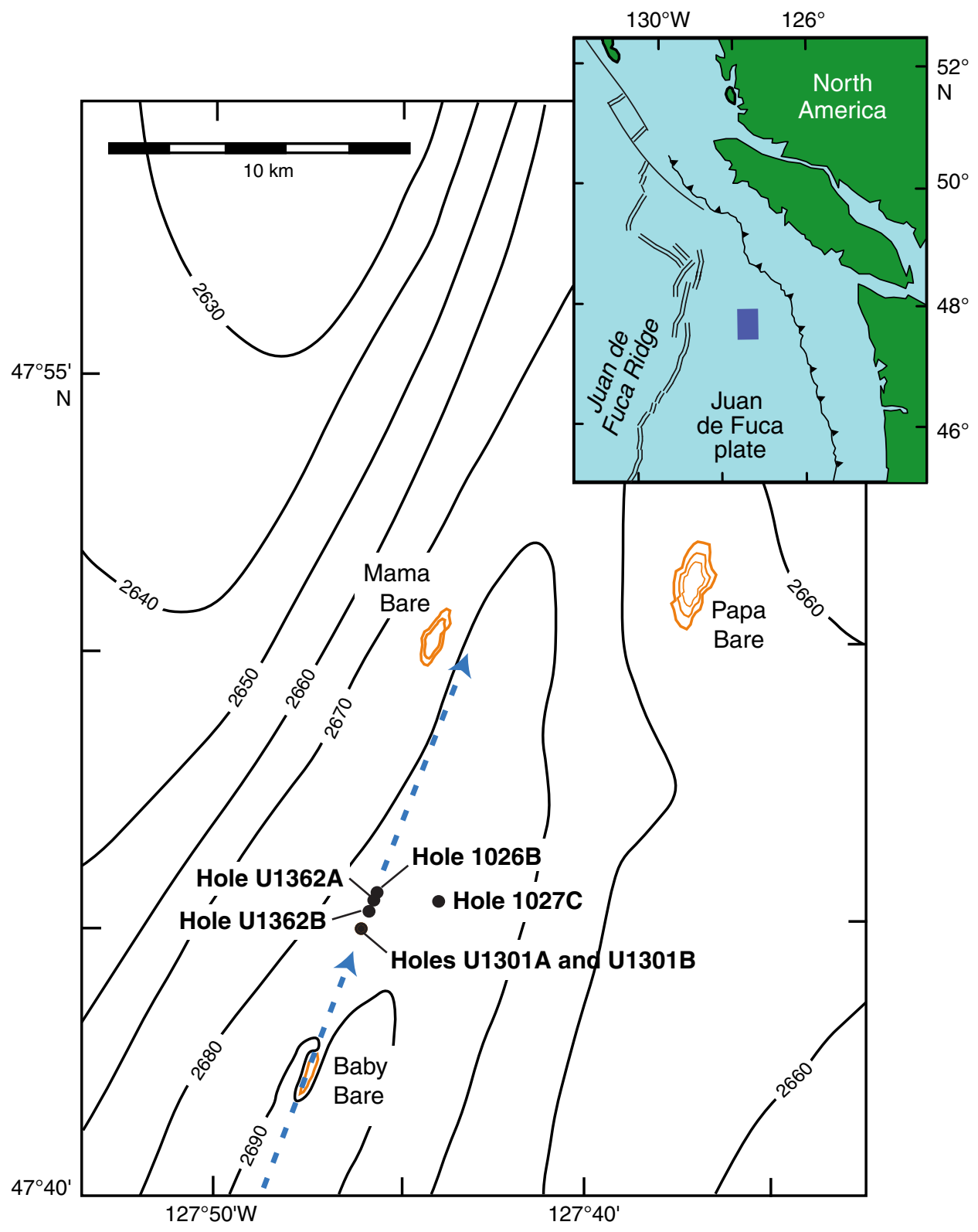


Figure F2. Cartoons illustrating hydrologic tracer concepts and geometry of Expedition 327 borehole injection operations. A. Natural flow system in which water moves laterally through a rock mass at a constant mass rate, $Q_{\text {in }}=Q_{\text {out }}$. Injectate is introduced at the upstream end of this system at a constant rate, $Q_{\text {inj, }}$ for a finite time. Tracer and natural formation fluid are transported downstream, with tracer mixing, spreading, and exchanging with surrounding formation. B. Tracer is injected for a finite time, leading to formation of a plume. The plume spreads and is transported downstream over time. If tracer is conservative, mass in plume remains constant. C. Schematic chemographs of tracer concentration (breakthrough curves). At the upstream end, the period of constant tracer injection is represented with a square wave (solid line). At one or more downstream (monitoring) locations, the chemograph is attenuated, and the center of mass arrives at a time determined by the mean rate of transport (dashed line). The magnitude of the peak concentration is determined by the rate of dilution with unlabeled formation fluid. Farther downstream, or at a location oblique to the direction of most rapid transport, the chemograph will arrive later and be more strongly attenuated (dotted line). There can also be a chemograph at a single location that has multiple peaks if there are distinct fluid and tracer transport pathways through the formation. D. Schematic illustration of tracer injection geometry in Hole U1362B during Expedition 327. The casing running tool was used to seal the top of the $103 / 4$ inch casing rather than a packer. A piece of pipe at the base of a stinger (drill pipe extending below the casing running tool), contained an injectate fluid sampler and downhole pressure gauges. Additional seals between concentric casing strings ensured that injectate was forced to flow from the stinger into the formation rather than back up to the seafloor. (Figure shown on next page.) 
Figure F2 (continued). (Caption shown on previous page.)
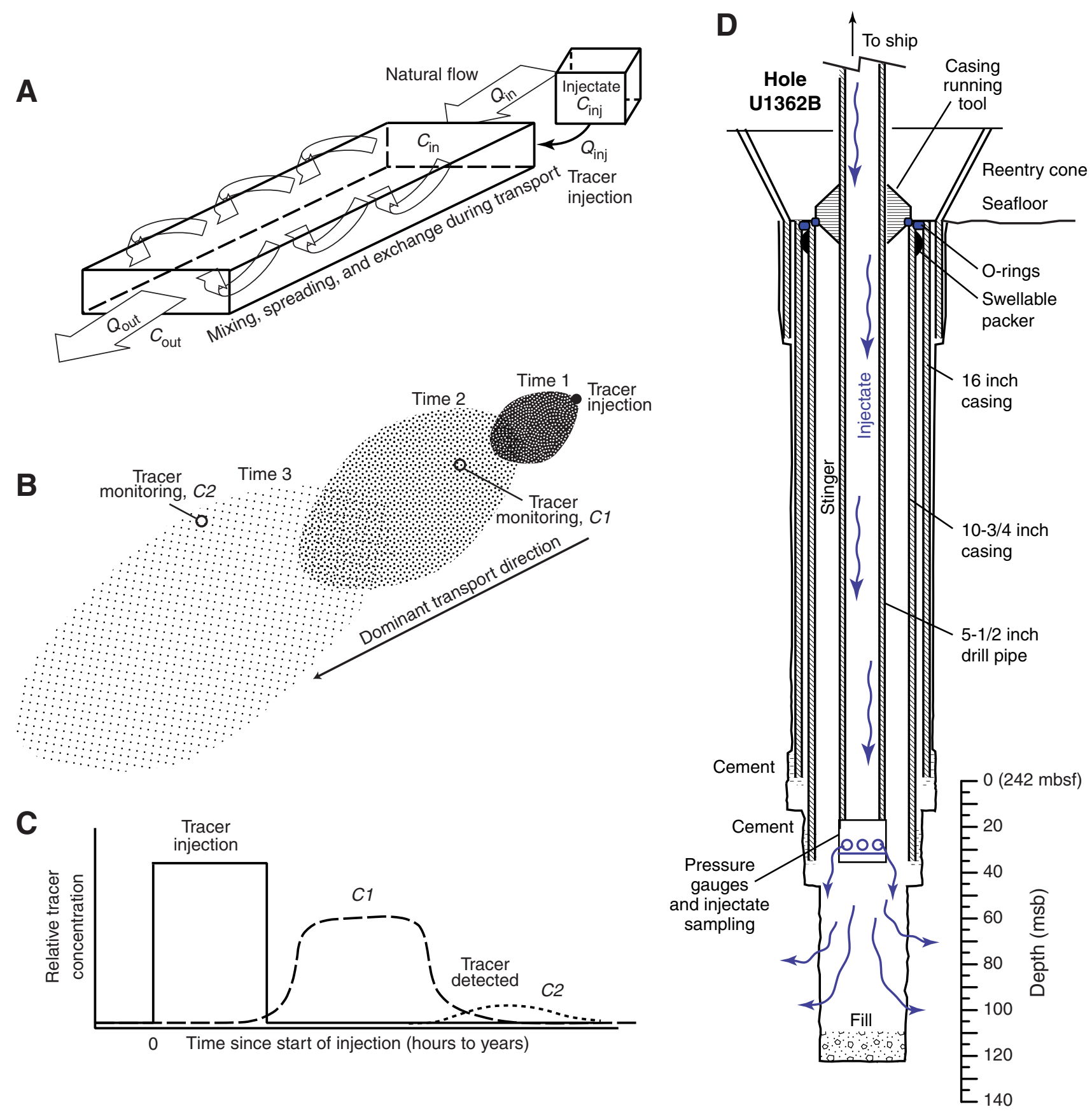
Figure F3. Schematic of shipboard tracer injection system during Expedition 327, illustrating pumps, manifolds, mixing points, and rig floor sampling location (not to scale). Mud pumps were used to inject fluid into the formation during the $24 \mathrm{~h}$ pumping experiment. Sulfur hexafluoride $\left(\mathrm{SF}_{6}\right)$ gas was introduced upstream from the mud pumps using an injection manifold (Fig. F4) to control the gas concentration. $\mathrm{V}=$ sampling valve, $V_{s}=$ switching valve, $C V$ = check valve, $G=$ pressure gauge. Fluid exiting the mud pumps was directed to the rig floor, where it entered the drill pipe. For several brief periods, additional tracers were added to this flow using the cement pump system. Seawater was mixed with salt tracers, and seawater or freshwater was mixed with solutions containing fluorescent microspheres or microbes and then added to the flow generated with the mud pump system. A sample port installed on the rig floor allowed collection of injectate samples before they were pumped into the drill pipe.

Cement pump room

(upper tween deck)

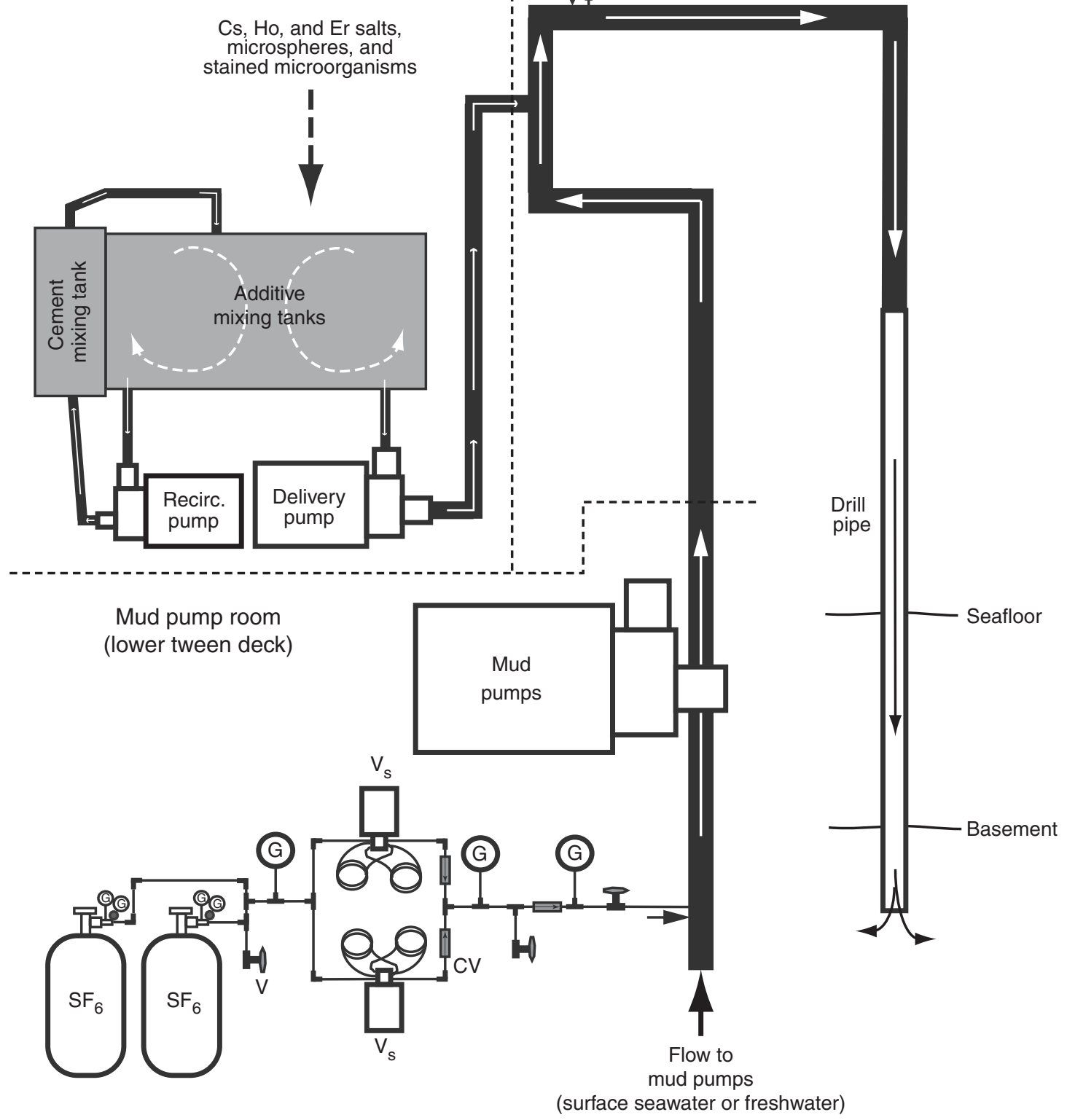


Figure F4. Diagrams of the $\mathrm{SF}_{6}$ tracer injection manifold and switching valves. A. Manifold. $\mathrm{SF}_{6}$ was introduced from two bottles (one at a time) containing the tracer in liquid form at $\sim 320$ psi. A two-stage regulator on each bottle was used to adjust the gas pressure relative to that in the standpipe upstream of the mud pumps (Fig. F3). Eight-port switching valves were used to inject fixed quantities of $\mathrm{SF}_{6}$ gas at $30 \mathrm{~s}$ intervals. Check valves prevented backflow of standpipe fluid into the tracer injection manifold. $P_{\text {bot }}=$ analog pressure at outlet to twostage regulator on $\mathrm{SF}_{6}$ tracer bottle. $\mathrm{LP}=$ low pressure, $\mathrm{HP}=$ high pressure. $P_{\text {dig- } 1}$ and $P_{\text {dig- } 2}=$ digital pressure gauges used to monitoring pressure upstream and downstream from the switching valves, respectively. $V_{s}=$ switching valve. $P_{\text {out }}=$ analog gauge used to monitor pressure at the standpipe. B. Switching valves alternate flow of gas between two $20 \mathrm{~mL}$ coils of stainless steel tubing. In one position, one coil empties while the other coil fills. When the valve switches, the previously filled coil empties while the empty one fills. Two valves were run in parallel during the $\mathrm{SF}_{6}$ injection experiment, delivering the contents of four coils $/ \mathrm{min}$, as described in the text.

A
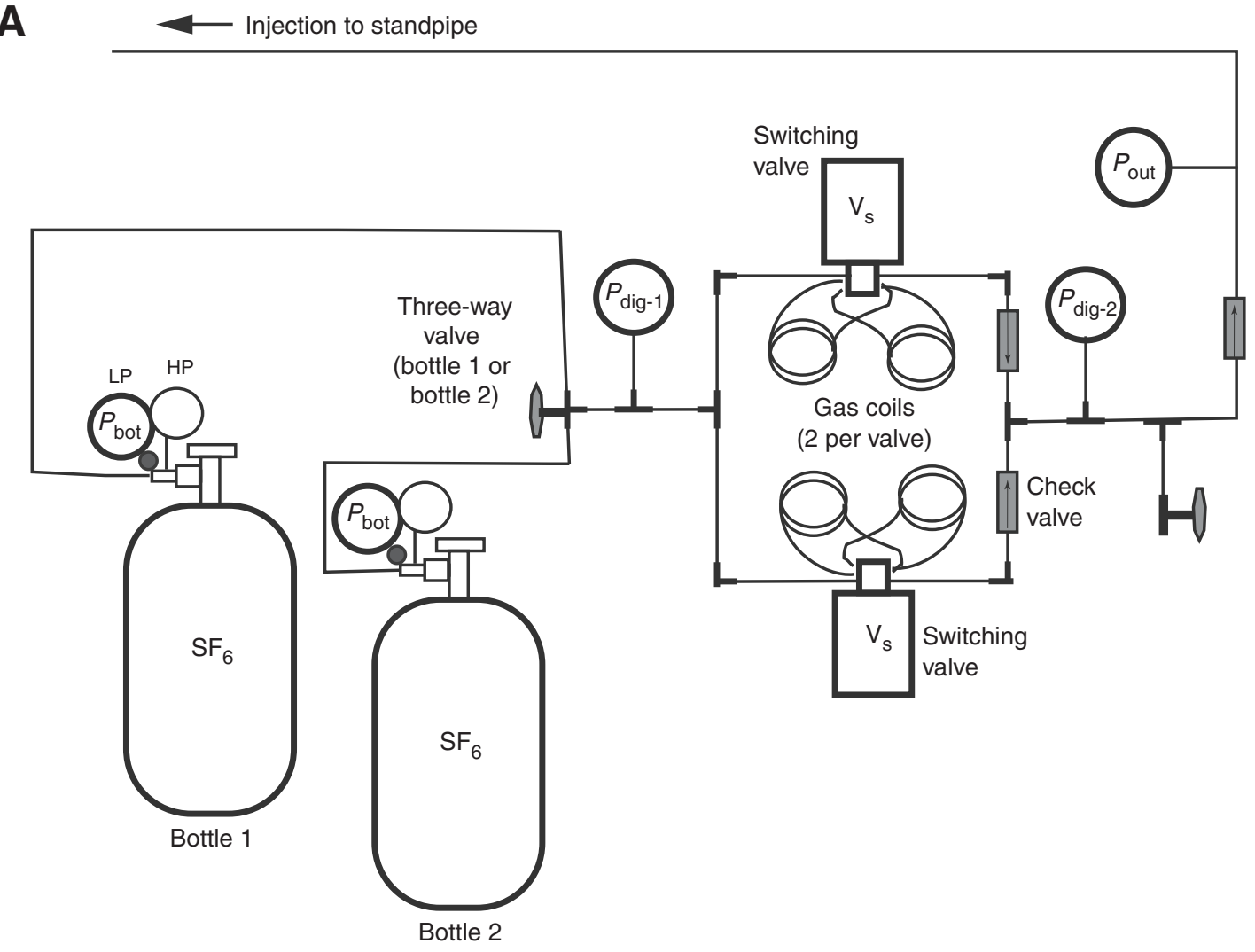

B Position 1
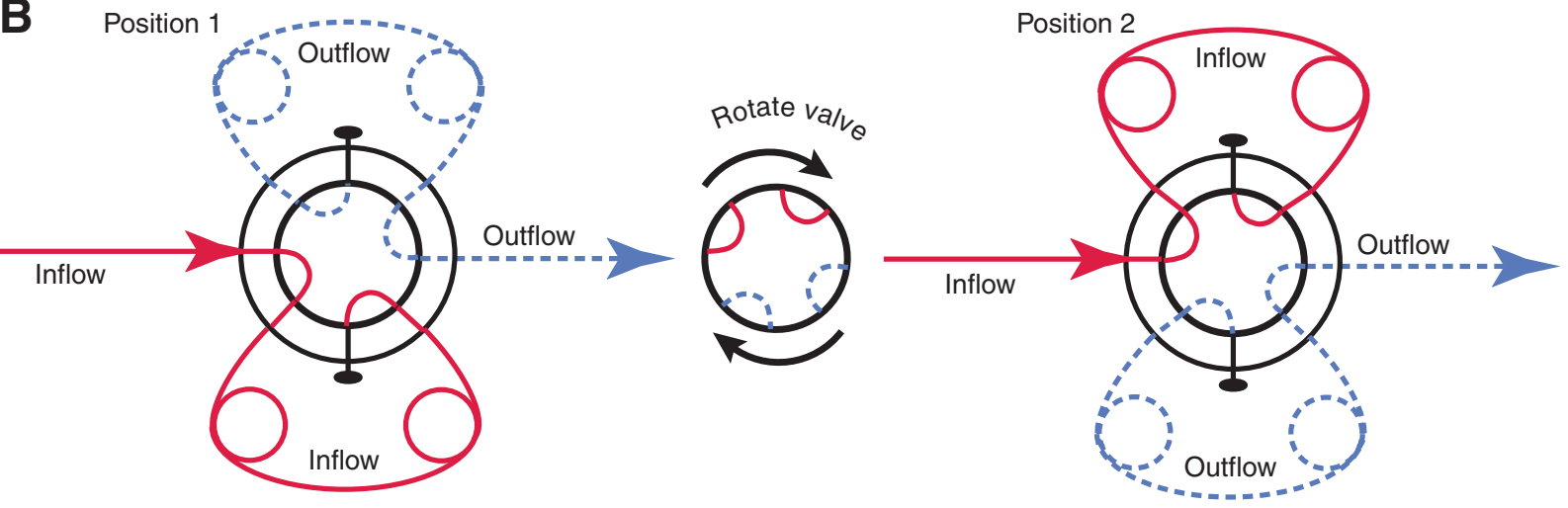
Figure F5. Plot of $\mathrm{SF}_{6}$ manifold calibration results, Expedition 327. Stainless steel coils attached to the eightport switching valves (Fig. F4) were calibrated by injecting air into the valves at known pressures and monitoring the volume of air at standard temperature and pressure (STP) that exited the manifold. The latter measurement was made by inverting a $1 \mathrm{~L}$ bottle filled with water in a bucket full of water and determining the volume of water displaced by air resulting from a known number of valve actuations. This experiment was repeated multiple times at several differential pressures, developing a linear relation between differential pressure and the volume of gas (at nominal STP conditions) that was passed through the manifold for each valve actuation. The differential pressure used for much of the tracer injection experiment was $\sim 80 \mathrm{psi}(\sim 540 \mathrm{kPa})$, so that the nominal injection rate was $\sim 116 \mathrm{~mL} /$ valve actuation of $\mathrm{SF}_{6}$ gas at STP, although values for each of the two valves were slightly different (as indicated by different slopes on plot). The $\mathrm{SF}_{6}$ bottles were run one at a time, but two switching valves were operated throughout the period of tracer injection, each switching at $30 \mathrm{~s}$ intervals, giving a nominal injection rate of $474 \mathrm{~mL} \mathrm{STP} / \mathrm{min}$ of $\mathrm{SF}_{6}$ gas.

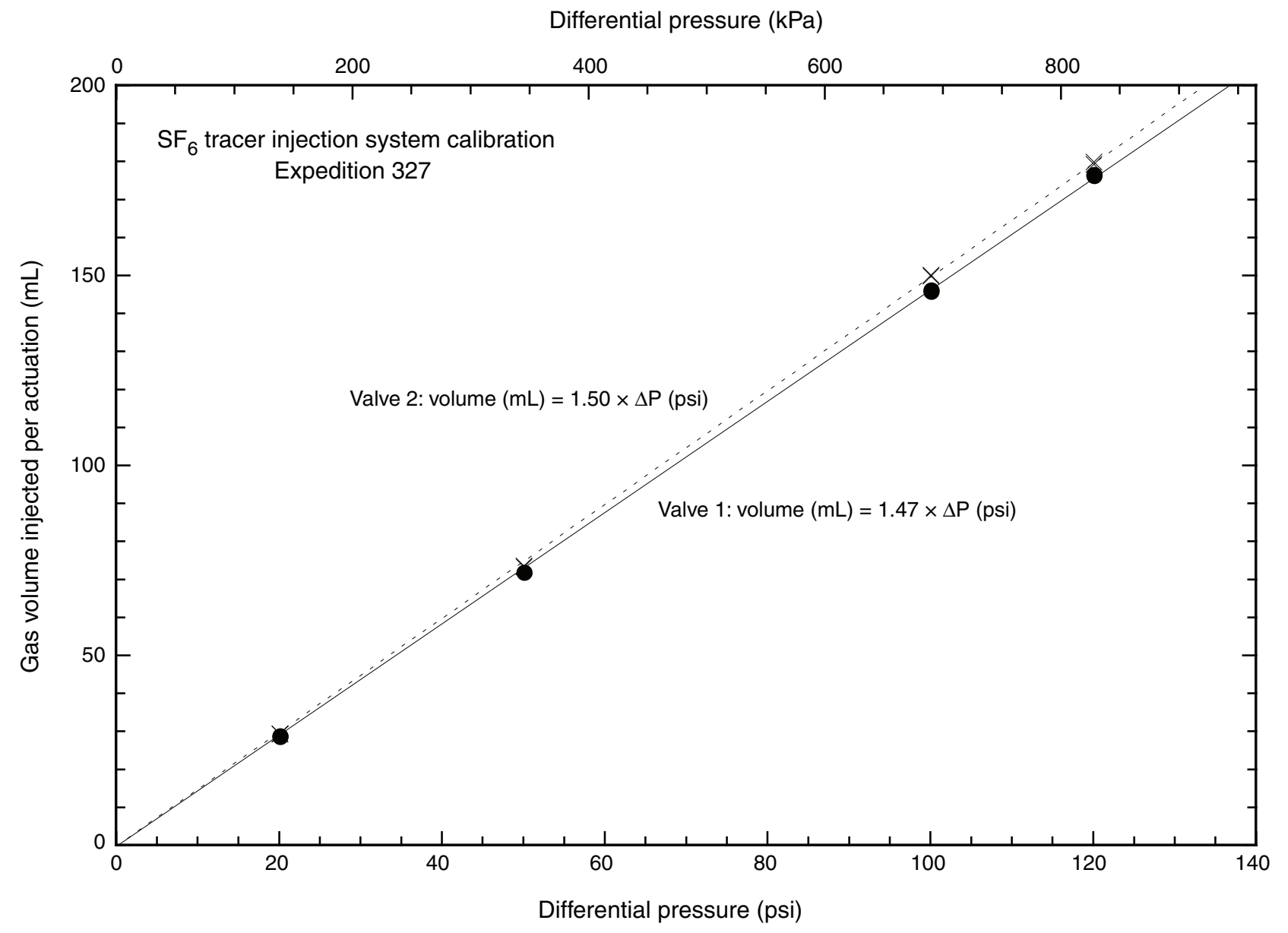


Figure F6. Photographs of $\mathrm{SF}_{6}$ injection manifold and components as deployed during Expedition 327. A. Tracer gas bottles, regulators, and injection manifold mounted on rail in mud pump room. Gas entered manifold on the left and exited on the right. Gas exiting manifold was directed through $1 / 8$ inch stainless steel line to an inlet port on standpipe located behind manifold. This standpipe is pressurized with a positive displacement pump (generally to $\sim 42 \mathrm{psi}$ ) and fed into the primary shipboard mud pump system. UPS = uninterruptable power supply. $\mathbf{B}$. $\mathrm{SF}_{6}$ bottle in use during experiment. Each bottle contained $\sim 1 \mathrm{~kg}$ of $\mathrm{SF}_{6}$ in liquid form at $\sim 320$ psi, with outlet pressure from the bottles determined during the experiment using two-stage regulators. Pressure was adjusted to achieve desired differential pressure between the regulator (inlet) and standpipe pressure (outlet). C. Switching valve, actuator, and two gas coils (made from $1 / 4$ inch stainless steel tubing). D. Detail of switching valve showing $1 / 16$ inch inlet lines and gas flow direction through tubing and coils (arrows).
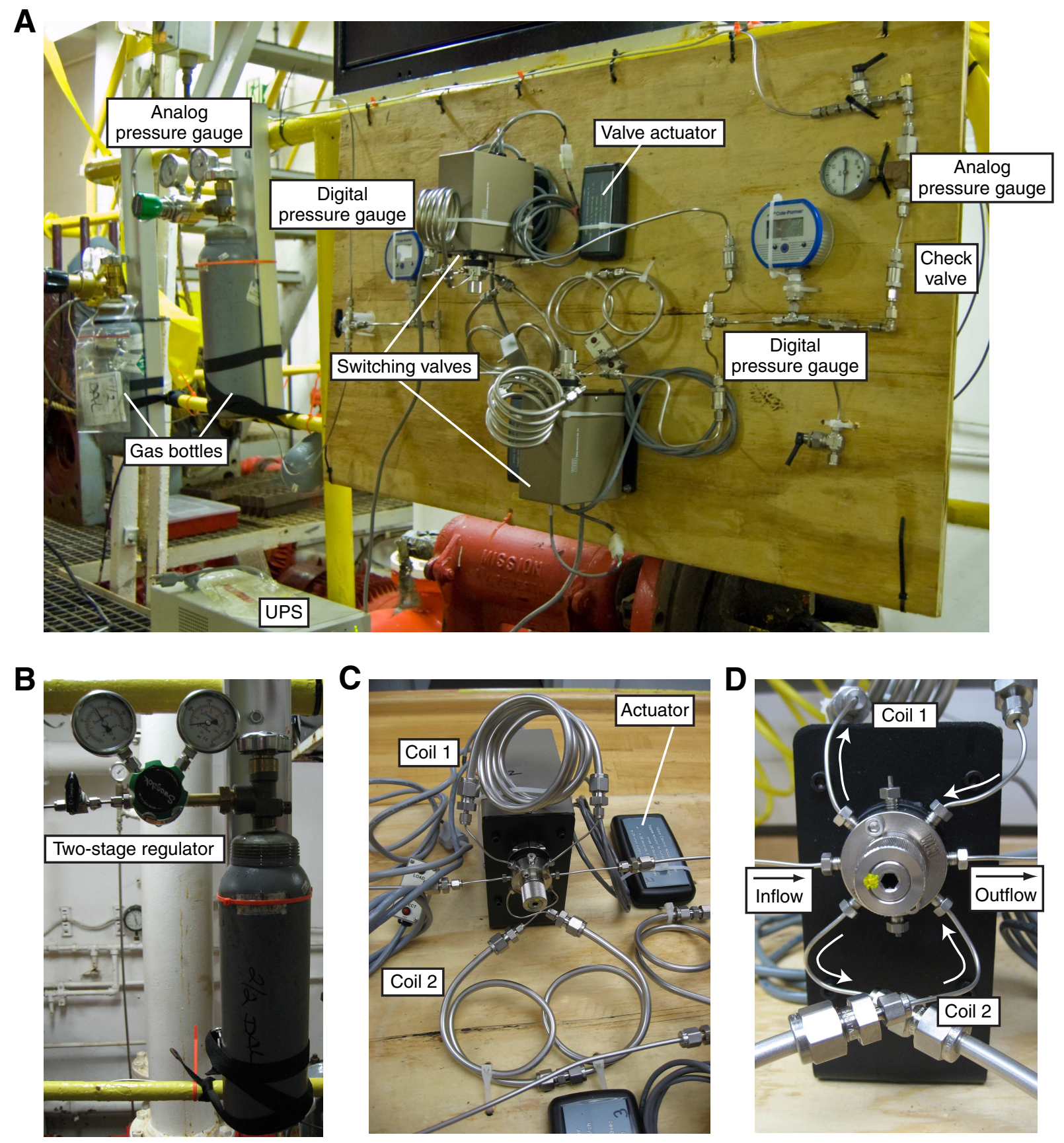
Figure F7. Photographs of salt and fluorescent particles being prepared for injection. $\mathrm{A}$. $\mathrm{ErCl}_{3}$ salt being dissolved in $20 \mathrm{~L}$ buckets before being placed in cement additive tank and diluted with seawater. The same procedure was used for $\mathrm{CsCl}$ and $\mathrm{HoCl}_{3}$ salts. B. Fluorescent microspheres dispersed in freshwater in a carboy before being placed in cement additive tank with additional freshwater. C. Cement additive tank during circulation of fluorescent microspheres in freshwater. Tank holds up to $1200 \mathrm{~L}$ of fluid, which was circulated internally to keep salts dissolved and particles suspended during injection into flow from the mud pump. Salts and fluorescent materials were added during two brief (5-9 $\mathrm{min}$ ) periods as part of the $24 \mathrm{~h}$ injection experiment.
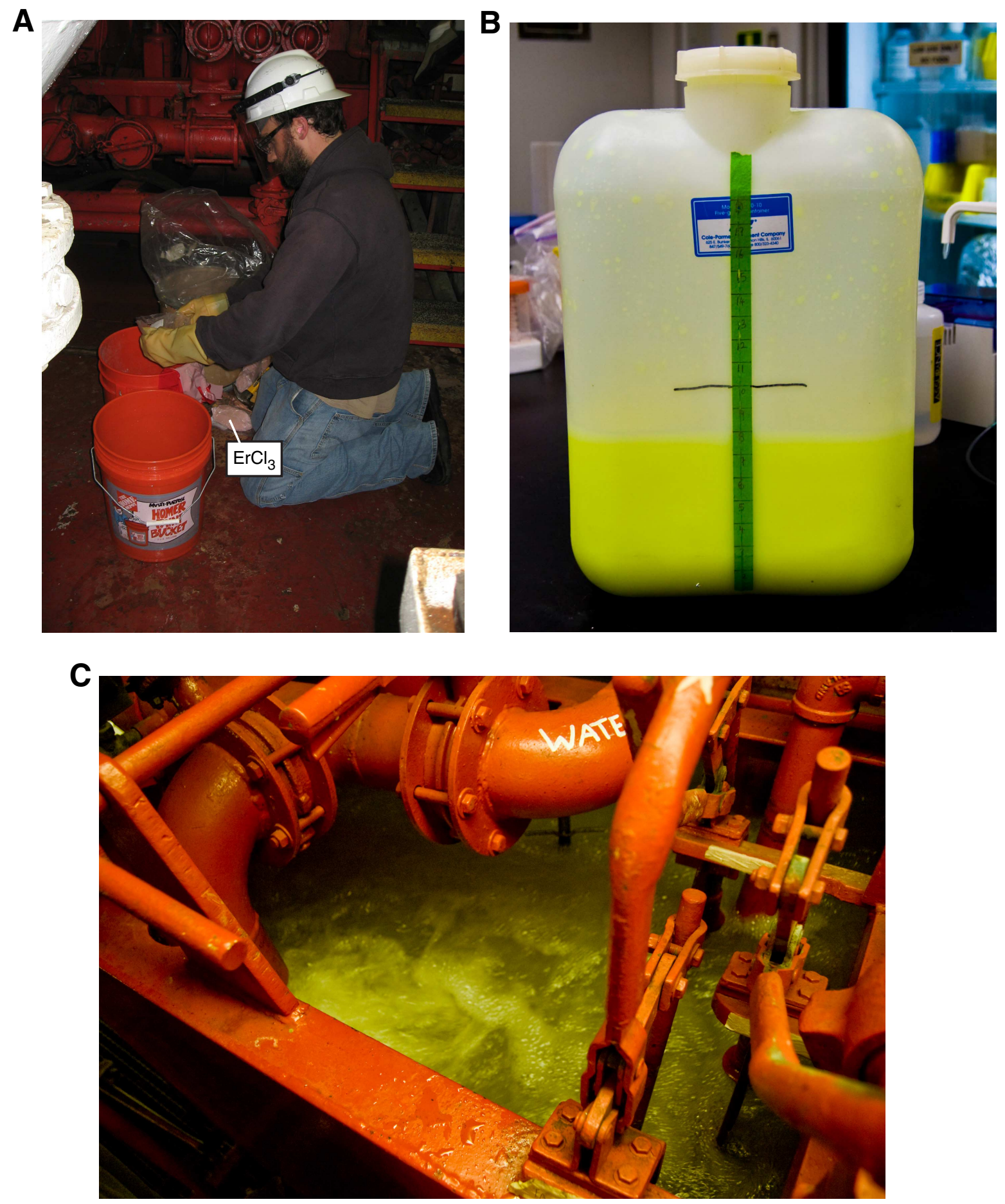
Figure F8. Photographs and drawing of tracer injectate sampling systems. A. Table on rig floor set up with sampling containers and related supplies. Samples were collected to determine concentrations of various tracers added throughout the injection experiment. $\mathrm{SF}_{6}$ samples were collected in preevacuated glass vacutainers and precut lengths of $1 / 4$ inch copper tube (crimped during sampling). Microbiology samples were collected in sterile plastic vials. Salt samples were collected in acid-washed HDPE screw-top bottles. Synchronized operations clocks placed on the rig floor, in the mud room (where $\mathrm{SF}_{6}$ was injected), and in the driller's shack helped to co-register pumping, tracer addition, and sampling events. B. Technician R. Gjesvold collects a rig floor sample using valve plumbed to standpipe adjacent to rig plumbing. C. Preparation of reverse-osmosis (RO) sampler deployed at end of stinger, where fluids exit the drill pipe and enter the formation. Sampler includes RO pumps (at top of image), and two coils each of PTFE and copper tubing (both $1.2 \mathrm{~mm}$ ID). D. RO sampler being deployed into carrier at end of stinger on rig floor, prior to reentry of Hole U1362B and start of injection experiment. E. Configuration of pipe positioned at end of stinger (Fig. F2) used to carry the RO sampler and pressure gauges. Slots in the pipe permitted injectate to exit the stinger and enter the formation, and holes into a separate chamber at the base of the pipe allowed downhole pressure gauges to determine borehole fluid pressure. (Figure shown on next page.) 
Figure F8 (continued). (Caption shown on previous page.)

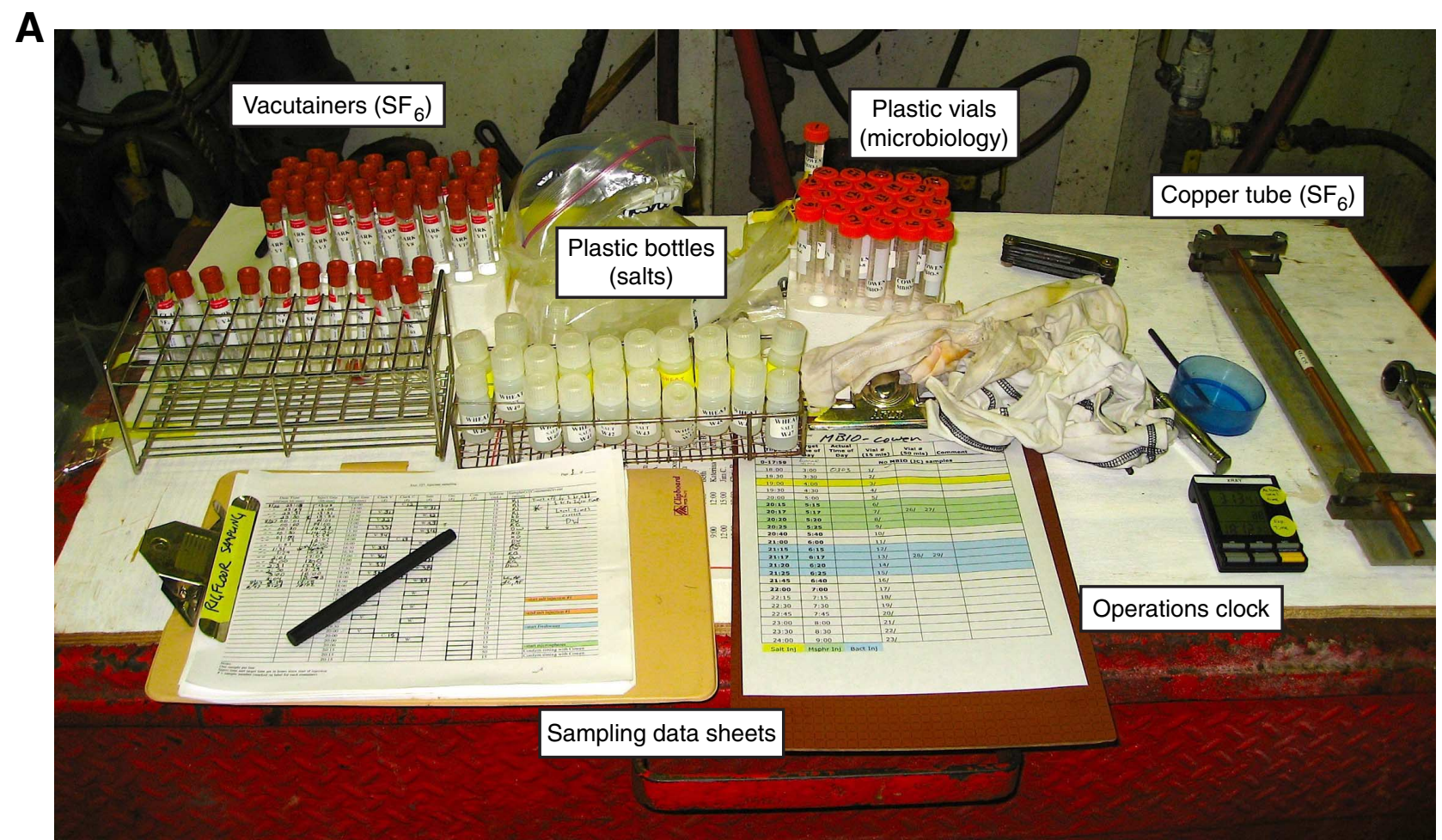

B

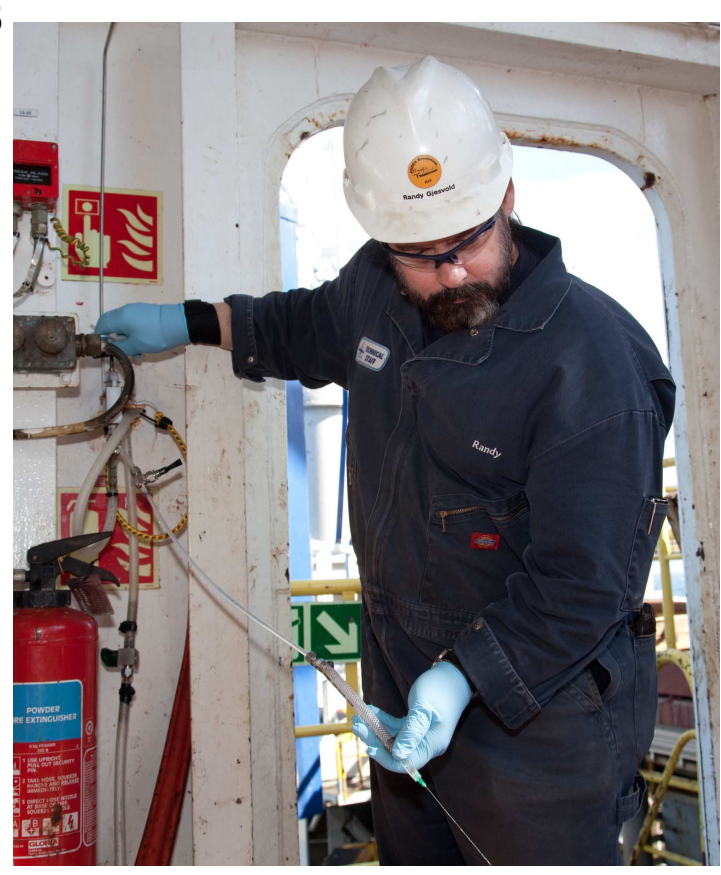

C

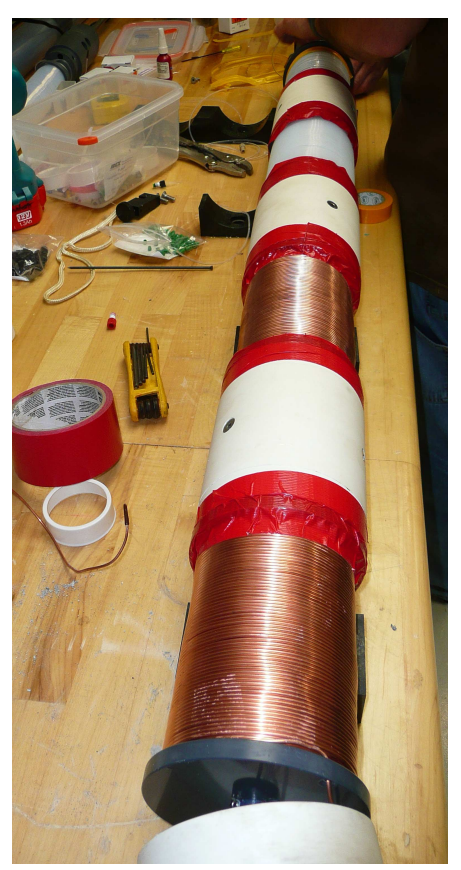

D

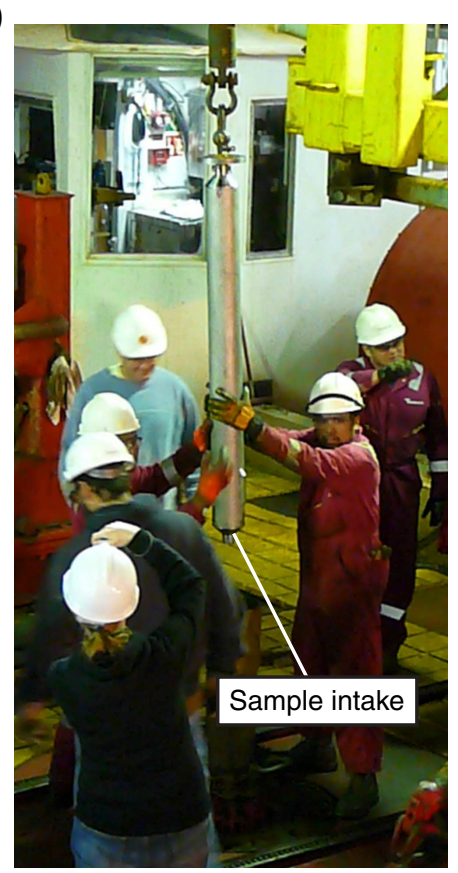

E

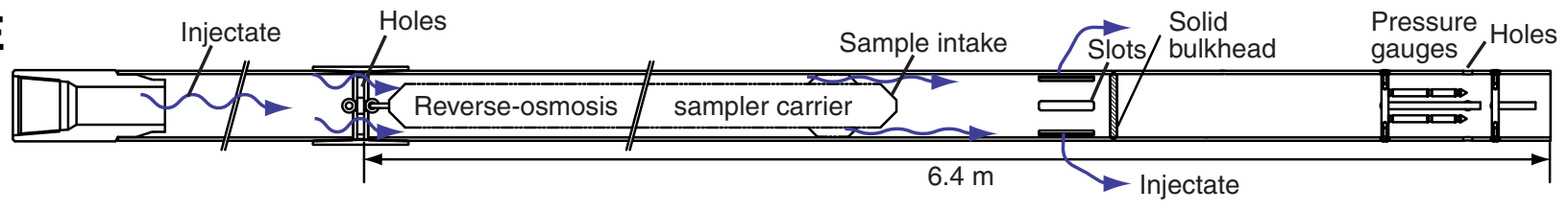


Figure F9. Plots showing variations in pumping rates and tracer concentrations during injection experiment, Expedition 327. Values are based on $1 \mathrm{~s}$ pumping records generated by the shipboard RIS, downsampled to $1 / \mathrm{min}$, and measured quantities of tracers injected during known time periods. Actual concentrations and tracer masses injected will be determined based on the composition of injectate samples. A. Flow rate. The mud pump was run at a constant rate of $\sim 6.7 \mathrm{~L} / \mathrm{s}$. The cement pump added injectate four times during the experiment, briefly increasing total injection rate into the formation. B. Injectate salinity and $\mathrm{SF}_{6} \mathrm{Concen}$ tration. $\mathrm{SF}_{6}$ was added using a regulator and valve manifold connected to the standpipe upstream of the mud pump. A nearly constant differential pressure was used to inject the gas at a fixed concentration, except when flow from the cement pump was added, briefly reducing the $\mathrm{SF}_{6}$ concentration but having no influence on the mass rate of $\mathrm{SF}_{6}$ injection. Seawater was the primary injectate, except for two $1 \mathrm{~h}$ periods when freshwater was injected. At two other times when Cs, Er, and Ho salts were added, injectate salinity increased. C. Concentrations of Cs, Er, and Ho salts and estimates of the concentrations of fluorescent microspheres and stained microbes. (Figure shown on next page.) 
Figure F9 (continued). (Caption shown on previous page.)

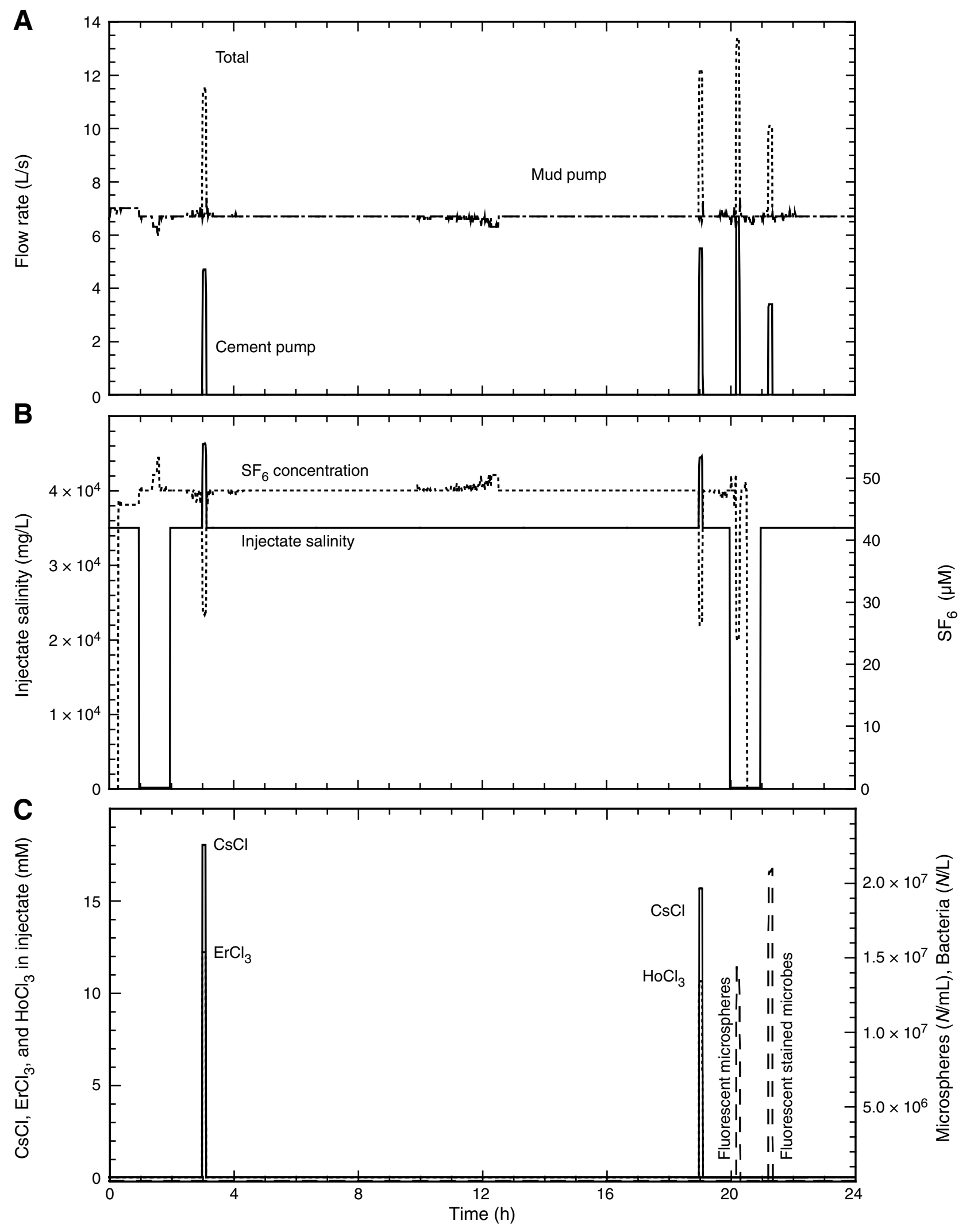


Figure F10. Graphic illustration of tracer injection and transport experiment planned for Expedition 327. Borehole locations and designs are schematic and not to scale. The old CORK installed in Hole 1027C could not be replaced during Expedition 327, as originally planned, but this remains a viable site for pressure monitoring of cross-hole response, and it may be possible to retrofit the CORK for fluid sampling as well. All of the CORKs currently sampling borehole fluids are oriented along a trend parallel to structural strike in this area, the direction inferred to be favored for fluid and advective (heat, solute, and particle) transport in basement. Samples collected from these CORKs in summer 2011 and 2012 will allow assessment of transport rates and hydrologic properties within this ridge-flank hydrothermal system.

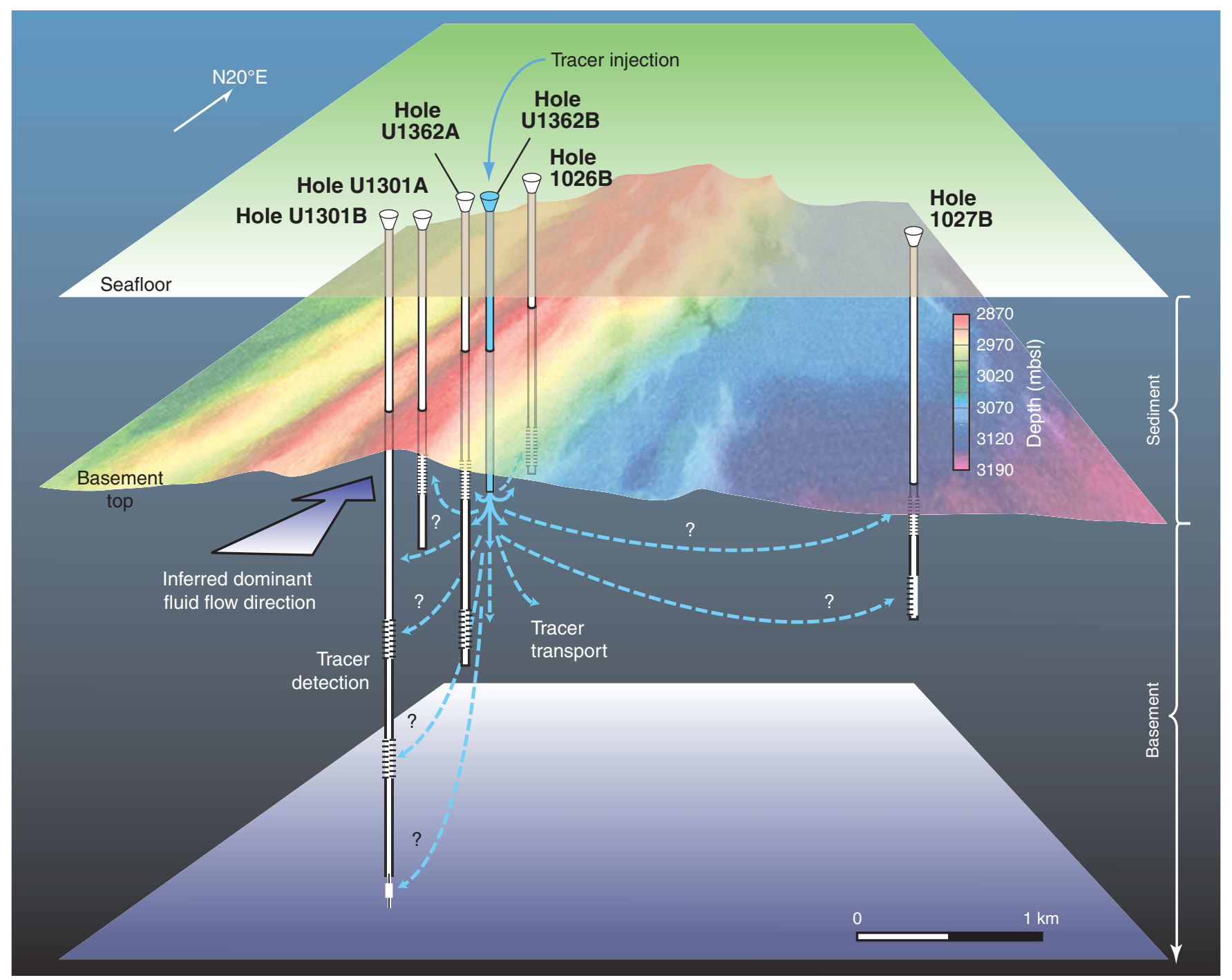


Table T1. Characteristics of tracers injected during $24 \mathrm{~h}$ pumping experiment, Expedition 327. (See table notes.)

\begin{tabular}{|c|c|c|c|c|c|c|}
\hline Tracer & Quantity & $\begin{array}{l}\text { Injection } \\
\text { duration }\end{array}$ & $\begin{array}{l}\text { Mean injectate } \\
\text { concentration }\end{array}$ & $\begin{array}{l}\text { Concentration in } \\
\text { bottom seawater* }\end{array}$ & $\begin{array}{l}\text { Detection } \\
\text { limit }\end{array}$ & $\begin{array}{l}\text { Dilution } \\
\text { factor }\end{array}$ \\
\hline $\mathrm{SF}_{6}$ & $\begin{array}{l}3.40 \mathrm{~kg} \\
23.3 \mathrm{~mol}\end{array}$ & $20.22 \mathrm{~h}$ & $47.6 \mu \mathrm{M}$ & ND & $0.07 \mathrm{pM}$ & $\sim 7 \times 10^{8}$ \\
\hline Cs (as CsCl) & $\begin{array}{l}2 \times 15 \mathrm{~kg} \\
2 \times 89.1 \mathrm{~mol}\end{array}$ & $\begin{array}{l}7.5 \mathrm{~min} \\
8 \mathrm{~min}\end{array}$ & $\begin{array}{l}18.0 \mathrm{mM} \\
15.6 \mathrm{mM}\end{array}$ & $2.2 \mathrm{nM}$ & $0.1 \mathrm{nM}$ & $\begin{array}{l}\sim 8 \times 10^{6} \\
\sim 7 \times 10^{6}\end{array}$ \\
\hline $\mathrm{Er}\left(\right.$ as $\left.\mathrm{ErCl}_{3} \cdot 6 \mathrm{H}_{2} \mathrm{O}\right)$ & $\begin{array}{l}23 \mathrm{~kg} \\
60.3 \mathrm{~mol}\end{array}$ & $7.5 \mathrm{~min}$ & $12.2 \mathrm{mM}$ & $9.6 \mathrm{pM}$ & $0.1 \mathrm{nM}$ & $\sim 1 \times 10^{9}$ \\
\hline $\mathrm{Ho}\left(\right.$ as $\left.\mathrm{HoCl}_{3} \cdot 6 \mathrm{H}_{2} \mathrm{O}\right)$ & $\begin{array}{l}23 \mathrm{~kg} \\
60.6 \mathrm{~mol}\end{array}$ & $8 \mathrm{~min}$ & $10.6 \mathrm{mM}$ & $2.7 \mathrm{pM}$ & $0.02 \mathrm{pM}$ & $\sim 3 \times 10^{9}$ \\
\hline BB Coumarin, $1.0 \mu \mathrm{m}^{\dagger}$ & $4.5 \times 10^{12}$ spheres & $6 \mathrm{~min}$ & $2 \times 10^{6}$ spheres $/ \mathrm{mL}$ & ND & $1 / \mathrm{mL}$ & $\sim 2 \times 10^{6}$ \\
\hline YG Fluorescein, $1.1 \mu \mathrm{m}^{\dagger}$ & $2.3 \times 10^{13}$ spheres & $6 \mathrm{~min}$ & $1 \times 10^{7}$ spheres $/ \mathrm{mL}$ & ND & $1 / \mathrm{mL}$ & $\sim 1 \times 10^{7}$ \\
\hline BB Coumarin, $0.49 \mu \mathrm{m}^{\dagger}$ & $3.6 \times 10^{13}$ spheres & $6 \mathrm{~min}$ & $2 \times 10^{7}$ spheres $/ \mathrm{mL}$ & ND & $1 / \mathrm{mL}$ & $\sim 2 \times 10^{7}$ \\
\hline DAPI-stained cells & $10^{11}$ cells & $8 \min$ & $\sim 10^{4}$ cells $/ \mathrm{mL}$ & ND & $1 / \mathrm{mL}$ & $\sim 10^{4}$ \\
\hline Freshwater (chlorinity) & $48,000 \mathrm{~L}$ total & $2 \mathrm{~h}$ & $0 \mathrm{mmol} / \mathrm{kg}$ & $542 \mathrm{mmol} / \mathrm{kg}$ & $1 \mathrm{mmol} / \mathrm{kg}$ & $\sim 5 \times 10^{2}$ \\
\hline
\end{tabular}

Notes: ${ }^{*}=\mathrm{SF}_{6}$, fluorescent microspheres, and fluorescent-stained microbes are entirely anthropogenic and so would not be detected in the bottom water of the northeastern Pacific Ocean except where introduced. Bottom water concentrations for trace metals from this area are from Hulme et al. (2008) and Wheat et al. (2010). Detection limits for $\mathrm{SF}_{6}$ are from Clark et al. (2005) and those for trace metals are from Hulme et al. (2008). Detection limits for fluorescent microspheres and stained microbes could be greater than indicated but will depend on fluid particle concentrations and visibility following filtering of samples. $\dagger=$ trade name of fluorescent dye and mean sphere diameter. Tracer: $\mathrm{SF}_{6}$ was injected as a dissolved gas through most of pumping test. $\mathrm{CsCl}+\mathrm{ErCl}_{3} \cdot 6 \mathrm{H}_{2} \mathrm{O}$ and $\mathrm{CsCl}+\mathrm{HoCl}_{3} \cdot 6 \mathrm{H}_{2} \mathrm{O}$ were injected as solutions in seawater during two brief periods. Fluorescent microspheres were injected in suspension in freshwater during a brief period. Fluorescent-stained bacteria were injected in suspension in seawater during a brief period. Mean injectate concentrations are estimated based on known quantities added and total rates of injectate pumping with mud pumps and cement pumps. Actual injectate concentrations will be determined as part of postexpedition analyses of samples collected on the rig floor and at the end of the stinger in the open hole. Dilution factors are calculated as (mean injectate concentration)/(detection limit) for $\mathrm{SF}_{6}$, fluorescent particles, and freshwater and as (mean injectate concentration)/(concentration in bottom seawater) for trace metals. Estimated DAPI-stained cell numbers are based on regional surveys of bacterial concentrations in surface seawater (e.g., Sherr et al., 2001). ND = not detected.

Table T2. Characteristics of fluorescent microspheres injected during tracer experiment, Expedition 327. (See table note.)

\begin{tabular}{lccc}
\hline \multicolumn{1}{c}{ Characteristic } & Microsphere 1 & Microsphere 2 & Microsphere 3 \\
\hline Product name & Fluoresbrite & Fluoresbrite & Fluoresbrite \\
Catalog number & 17458 & 17154 & $13772^{*}$ \\
Lot number & $573610 / 600854$ & $610907 / 607320$ & 616358 \\
Diameter $(\mu \mathrm{m})$ & 1.00 & 1.1 & 0.49 \\
Suspension volume $(\mathrm{mL})$ & 100 & 500 & 100 \\
Microsphere concentration (\%) & 2.6 & 2.6 & 2.5 \\
Dye compound & BB (Coumarin) & YG (Fluorescein) & BB (Coumarin) \\
Surface charge & Carboxyl & Plain & Plain \\
Excitation maximum $(\mathrm{nm})$ & 360 & 441 & 360 \\
Emission maximum $(\mathrm{nm})$ & 407 & 486 & 407 \\
\hline
\end{tabular}

Note: ${ }^{*}=$ custom order; other products are standard stock. 